\title{
Controlling Offsite Movement of Agricultural Chemical Residues: Walnuts
}

\section{INTRODUCTION}

TERRY PRICHARD, University of California Cooperative Extension Water Management Specialist; JOSEPH A. GRANT, University of California Cooperative Extension

Pomology Farm Advisor, San Joaquin County; LAWRENCE J. SCHWANKL, University of California Cooperative Extension Specialist, Kearney Agricultural Research and Extension Center his publication provides growers of walnuts with information on farming practices that can help reduce the occurrence of organophosphate and synthetic pyrethroid pesticides in surface water, including streams, lakes, ponds, rivers, and drainage ditches. It describes the current regulatory approach to surface water protection; gives background information on the safe and effective use of pesticides, integrated pest management, and handling runoff water; and demonstrates the self-assessment of the potential risk of offsite movement of an insecticide using flowcharts for specific management practices and orchard conditions in walnut. The risk self-assessment focuses on issues that affect either the number of pesticide applications containing certain active ingredients or the offsite movement of pesticides as drift, attached to sediment, or in water that carries pesticide active ingredients.

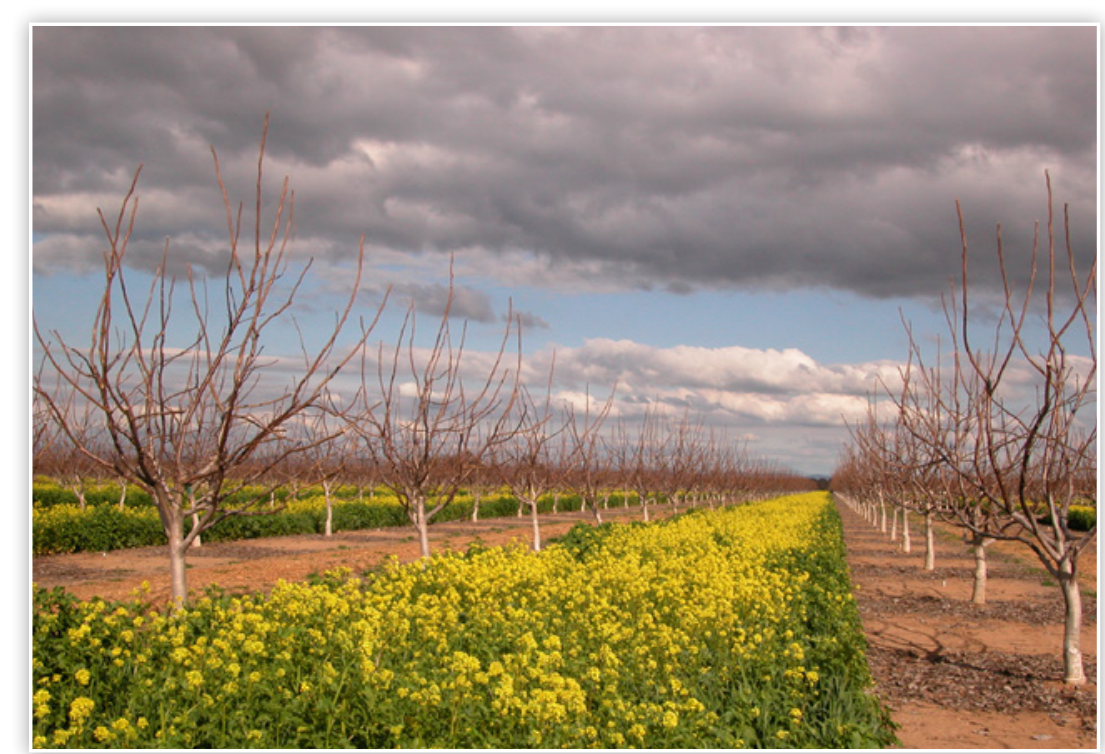

Photo by T. L. Prichard 
The publication concludes with research-based management practices that mitigate the risk that pesticide residues will leave the site of application and enter surface water.

More detailed information on implementation of many of these practices is available from sources cited throughout (see the references at the end of the publication). For assistance in determining which practices would be best for your operation or how to implement them, please contact your local UC Cooperative Extension farm advisor.

\section{Why Is This Publication Needed?}

The Central Valley occupies about $40 \%$ of the land area in California and provides much of the state's agricultural production. Maintaining this productivity resulted in the use of about 186 million pounds of pesticides in 2012 alone (PAN 2012). Water quality in the Central Valley's rivers and streams has been impacted in part due to pesticide movement from agricultural lands. The impaired water bodies recently proposed for listing under the Clean Water Act Section 303(d) include nearly a hundred water body segments in which impairment was due to agriculture. Agriculture is identified as the likely cause of impairment more often than any other pollution source in the state.

Agricultural pesticides reach surface water directly as spray drift or indirectly through irrigation or storm water runoff from treated fields, vineyards, and orchards. Runoff water may transport pesticides in dissolved form or as residues that adhere to soil particles. Among the pollutants often attributed to agriculture is the organophosphate insecticide chlorpyrifos. To indicate the extent of the problem, California agriculture uses $1,100,870$ pounds of chlorpyrifos annually, more than any other insecticide (PAN 2012). Approximately half of the 303(d)-listed water body segments impaired due to agriculture in the Central Valley are impaired in whole or in part by chlorpyrifos.
The total maximum daily load (TMDL) is a calculation of the maximum amount of a pollutant that a water body can receive and still meet water quality standards. The presence of chlorpyrifos in surface water and its toxicity to aquatic life has been responsible for multiple TMDL projects in California, including one for the San Joaquin River, another for the Sacramento-San Joaquin Delta, and many others in locations where the TMDL definition process is less developed. In one study, chlorpyrifos was responsible for mortality to the test organism Ceriodaphnia dubia in seven of ten toxic samples (de Vlaming et al. 2004).

Synthetic pyrethroids are also emerging as a concern. Pyrethroids are a cause for 303(d) listing in about $10 \%$ of agriculture-impaired water bodies in California. In a study of toxicity of sediments collected from agricultural waterways, 54 out of 200 sediment samples caused acute toxicity to the test organism Hyalella azteca, and pyrethroids were responsible for the toxicity in $61 \%$ of those cases (Weston et al. 2009). Chlorpyrifos was the second-most-common contributor to toxicity, responsible for toxicity in $20 \%$ of the samples. Recent data also indicate that pyrethroids are present at toxic levels in the water column of irrigation tailwater (runoff at the end of a field) samples. In a 2010 study, the pyrethroid lambda-cyhalothrin was responsible for toxicity to $H$. azteca in three out of six toxic samples collected at California agricultural pump stations where tailwater was being returned to nearby rivers; chlorpyrifos was responsible in the remaining three samples (Weston and Lydy 2010). As analyses of environmental samples for pyrethroids become more frequent, it is likely that the water quality effects of pyrethroids will be even more broadly recognized.

The continued use of these effective agricultural pesticides depends on implementing measures to prevent the offsite movement of pesticide residues into surface water. Table 1 gives 
Table 1. Selected walnut pesticides used in California in 2008 that are registered for use in 2011

\begin{tabular}{|l|l|c|l|}
\hline $\begin{array}{l}\text { Active ingredient } \\
\text { common name }\end{array}$ & Trade name* & $\begin{array}{c}\text { Volume used } \\
\text { (Ib/yr) }\end{array}$ & Chemical class \\
\hline methoxyfenozide & Intrepid & 7,896 & diacylhydrazine \\
\hline methidathion & Supracide & 1,062 & organochlorine \\
\hline chlorpyrifos & Lorsban & 174,931 & organophosphate \\
\hline phosmet & Imidan & 20,290 & organophosphate \\
\hline methyl parathion & Penn-Cap & 25,191 & organophosphate \\
\hline malathion & Malathion & 8,761 & organophosphate \\
\hline permethrin & Pounce & 7,338 & pyrethroid \\
\hline bifenthrin & Brigade & 8,423 & pyrethroid \\
\hline esfenvalerate & Asana XL & 1,695 & pyrethroid \\
\hline lambda-cyhalothrin & Warrior & 2,733 & pyrethroid \\
\hline pyriproxyfen & Esteem & 766 & pyridine \\
\hline spinetoram & Delegate & 795 & spinosyn \\
\hline imidacloprid & Provado & 4,081 & Neonicotinoid \\
\hline acetamiprid & Assail & 5,535 & Neonicotinoid \\
\hline chloroantraniliprole & Altacor & Ryanoid \\
\hline flubendiamide & Belt & Ryanoid \\
\hline & & 1,341 & \\
\hline
\end{tabular}

Source: California Department of Pesticide Regulation

Note: More than one trade name is used for some of the active ingredients

the active ingredients and trade names for insecticides used in walnut production with reported use over 500 pounds of active ingredient in California during 2012. Organophosphates and pyrethroids represent over $83 \%$ of this list, with chlorpyrifos, an organophosphate, being the highest-used product based on pounds applied per year.

\section{Current Regulatory Approach to Surface Water Protection}

All growers farm under a regulatory requirement not to pollute surface and groundwater. Water leaving agricultural lands as irrigation or storm water runoff can contain pesticide residues, sediment, and nutrients. These discharges in the Central Valley are regulated by California’s Central Valley Regional Water Quality Control Board under the Irrigated Lands Regulatory Program. Essentially, the board enforces the California Water Code of 1969 and the federal Clean Water Act of 1972. To this end, the water board has established surface water quality standards in each watershed basin plan and has enforced waste discharge requirements.

\section{The Ag Waiver}

In 1982 the Central Valley water board adopted the resolution "Waiving Waste Discharge Requirements for Specific Types of Discharge." The resolution contained 23 categories of waste discharges, including irrigation return flows and storm water runoff from agricultural lands. The resolution also listed the conditions required to comply with the waiver; hence the term "Conditional Ag Waiver." Due to a shortage of resources at the time, the water board did not impose measures to verify compliance with these conditions.

The waiver, set to sunset in 2003, was amended by adopting two conditional waivers for discharges from irrigated lands. One waiver was for coalition groups of individual dischargers to comply with the California Water Code and water board regulations. The second was for growers to comply as individual entities. To be covered by the waivers, the coalition or individual must have filed with the water board by November 1, 2003, a Notice of Intent and General Report that contained specific information about their farm and must have adhered to a plan and timeline that includes, among other things, a surface water monitoring plan.

\section{Water Quality Coalitions}

Water quality coalitions are generally formed by growers on a subwatershed basis. A few coalitions were formed for a specific commodity. The San Joaquin County and Delta Water Quality Coalition, for example, encompasses all of San Joaquin County and portions of Contra Costa, Alameda, and Calaveras Counties. The coalition includes about 500,000 acres of irrigated lands and 
represents 4,500 individual members. The coalition monitors and analyzes the water quality of subwatersheds in surface water and facilitates the implementation of management plans. Coalitions provide outreach and support to growers in response to water quality exceedances at subwatershed monitoring sites in order to enhance the water quality of affected water bodies.

\section{Water Quality Monitoring}

The San Joaquin County and Delta Water Quality Coalition currently monitors water quality at numerous sites in large and small subwatersheds in the coalition watershed. Water samples are collected monthly, and sediment samples are collected twice per year. During 2008, the level of a material being monitored exceeded water quality standards many times. At some locations, as many as $40 \%$ of the samples exceeded water quality standards for pesticide residues (Karkoski 2008). When more than one exceedance of water quality standards occurs for any contaminant, the coalition must develop a management plan to address it. In addition, any single exceedance of either chlorpyrifos or diazinon triggers the requirement for a management plan.

\section{Water Quality Management Plans}

The overall goal of water quality management plans, whether developed by individuals or coalition, is to reduce agricultural impacts on water quality in the plan area. Management plans evaluate the frequency and magnitude of exceedances and prioritize locations for outreach. To achieve the goal of improving water quality, a management plan must include

- identification of the source of constituents that impair water quality

- outreach to growers about irrigation and dormant-season management practices that protect water quality

- evaluation of water quality improvements by monitoring and implementing management practices

Under the management plan landowners or growers must
- help the coalition succeed by participating in efforts to solve water quality impairments identified through water quality monitoring

- stay informed by reading mailings and updates and responding as necessary

- attend grower water quality information meetings

- implement management practices that mitigate the identified water quality concerns

\section{How To Use This Publication}

This publication should be used in a two-step process. The first step is to make a risk evaluation of field conditions or operations to identify farming practices that may influence the risk of offsite pesticide movement. This risk evaluation is made using a series of flowcharts. Once avenues of possible pesticide movement from a particular orchard are identified in the first flowchart, succeeding flowcharts help identify specific conditions and operations that can reduce offsite movement. When followed systematically from beginning to end, the flowcharts guide the user through a step-bystep evaluation of a farming operation to identify potential problem areas. The section "Overview of Risk Evaluation" below describes how to use the flowcharts and contains sample sections of two flowcharts. The complete flowcharts can be found at the end of this publication.

The second step in the process is to understand and implement management practices that address problem areas. These management practices are divided into three broad areas: integrated pest management, water and soil management, and managing runoff water.

\section{Integrated Pest Management}

Use integrated pest management (IPM) practices and handle and apply pesticides correctly. IPM is an ecosystem-based strategy that focuses on long-term prevention of pests or their damage through a combination of techniques such as biological control, habitat manipulation, modification of cultural practices, and use of resistant varieties. Pesticides are used only after monitoring 
indicates that they are needed according to established guidelines, and treatments are made with the goal of removing only the target organism. Coupling IPM techniques with proper pesticide selection, handling, and application can mitigate the offsite movement of pesticide residues. These practices should be the foundation of any water quality protection program. Implementing at least some of them can also reduce risks to human health, beneficial and nontarget organisms, and the environment.

\section{Water and Soil Management}

Use soil and water management practices that reduce runoff potential. Runoff occurs when irrigation or rainfall delivers water faster than it can enter the soil. Runoff water can carry dissolved pesticides or transport eroded soil particles that have pesticides adsorbed on them into waterways. To help ensure that irrigation water needs are met and runoff is kept to a minimum, it is important to select the proper irrigation system, then design and operate it correctly. Soil management practices that promote water infiltration and irrigation efficiency include a reduction in tillage, especially when wet, to avoid compaction; increasing soil organic matter; grading the soil slope to accommodate irrigation uniformity; adding soil amendments as needed; and growing cover crops during the offseason to reduce winter rainfall runoff.

\section{Managing Runoff Water}

If IPM and water and soil management do not adequately address the offsite movement of pesticides, techniques for physically intercepting, recycling, or chemically treating must be considered.

\section{Overview of Risk Evaluation}

For an overview of the process, we will consider a sample northern San Joaquin Valley walnut orchard to illustrate how using the flowcharts and management information in this publication can identify and correct the offsite movement of an insecticide. A more detailed discussion of this case study is presented in the risk analysis case study at the end of this manual. The thick, shaded arrows in the flowcharts indicate the logical progression in considering effective management practices.

Orchard: Mature walnuts, 32 acres, not organic

Topography: 0 to $2 \%$ slope

Soil: Hollenbeck silty clay loam soil; soil tends to crust, limiting the water infiltration rate causing some runoff from mid to late season.

Irrigation water: $\mathrm{pH} 7.5, \mathrm{EC} 0.2 \mathrm{dS} / \mathrm{m}$

Irrigation system: Full-coverage sprinklers, application rate 0.10 in/hr

Irrigation operation: $50 \mathrm{hr}$ per 14-day period at midseason

Irrigation runoff: Runoff is relatively small in volume, carrying little or no sediment.

Drainage: Mid to late-summer runoff moves to a drainage ditch at edge of an orchard, then on to a larger creek.

Proximity to surface water: During the spring and summer, a drainage ditch along one edge of the orchard often contains irrigation runoff water from adjacent lands.

Pesticide mixing and loading: A pesticide mixing and loading area is located 40 feet from the drainage ditch.

\section{Using the Flowcharts}

We begin the risk assessment with Flowchart 1 (FC1), Offsite Movement Risk, which considers possible routes by which pesticide could move from the orchard and the operations or conditions that may contribute to the movement. The three possible areas of concern are the irrigation runoff risk, the storm water runoff risk, and the application near surface water risk". As an example, we will consider the Irrigation Runoff Risk following the example orchard's conditions. 
- Irrigation runoff risk (fig. 1). Pesticides may be carried in the runoff that occurs during pressurized irrigation after the pesticide application. Go to FC2.

- Pressurized irrigation runoff risk (fig. 2). Following the shaded arrow leads us to consider IPM practices, pesticide selection, and mixing and loading practices to reduce offsite movement of pesticide residues. At each step we are directed to specific areas of the management section for ways they can be implemented. We are then directed to consider the irrigation system management, irrigation scheduling, capturing or recycling runoff, and, finally, ways that runoff water (if it still occurs) could be treated to reduce any pesticide residues it may contain.

FC2

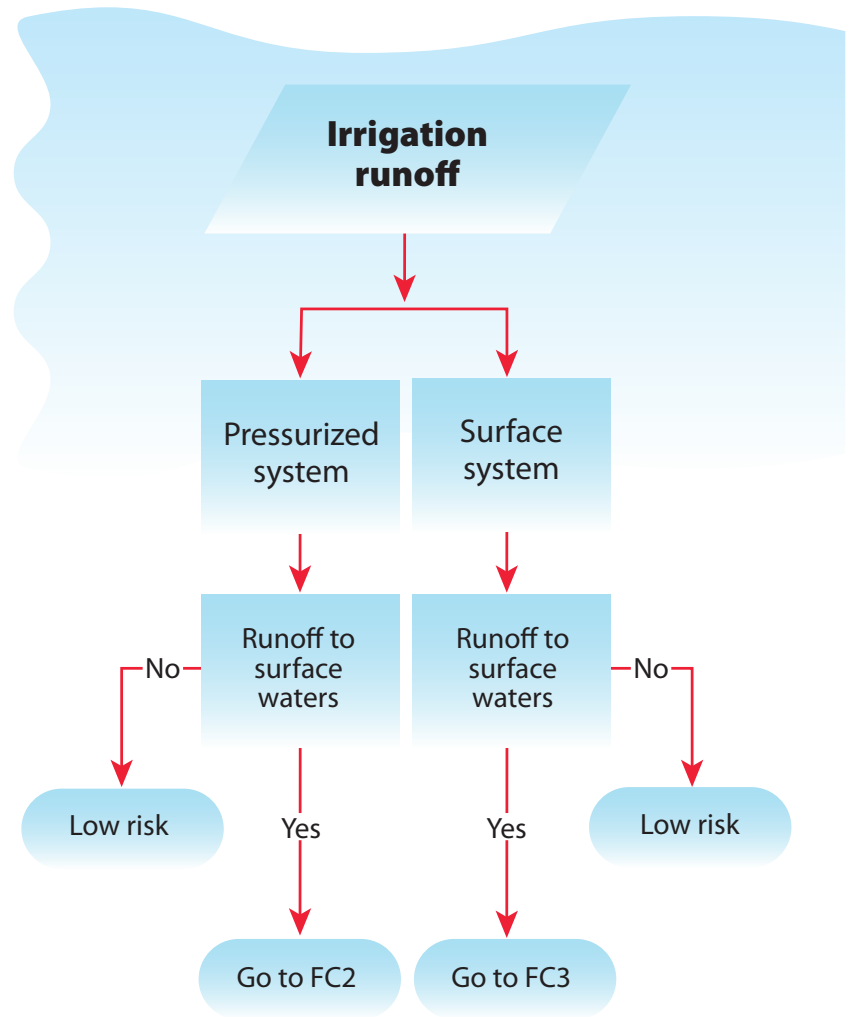

Reducing the Risk of Offsite Movement of Ag Chemicals in Runoff Pressurized Irrigation Systems

Runoff to surface waters occurs
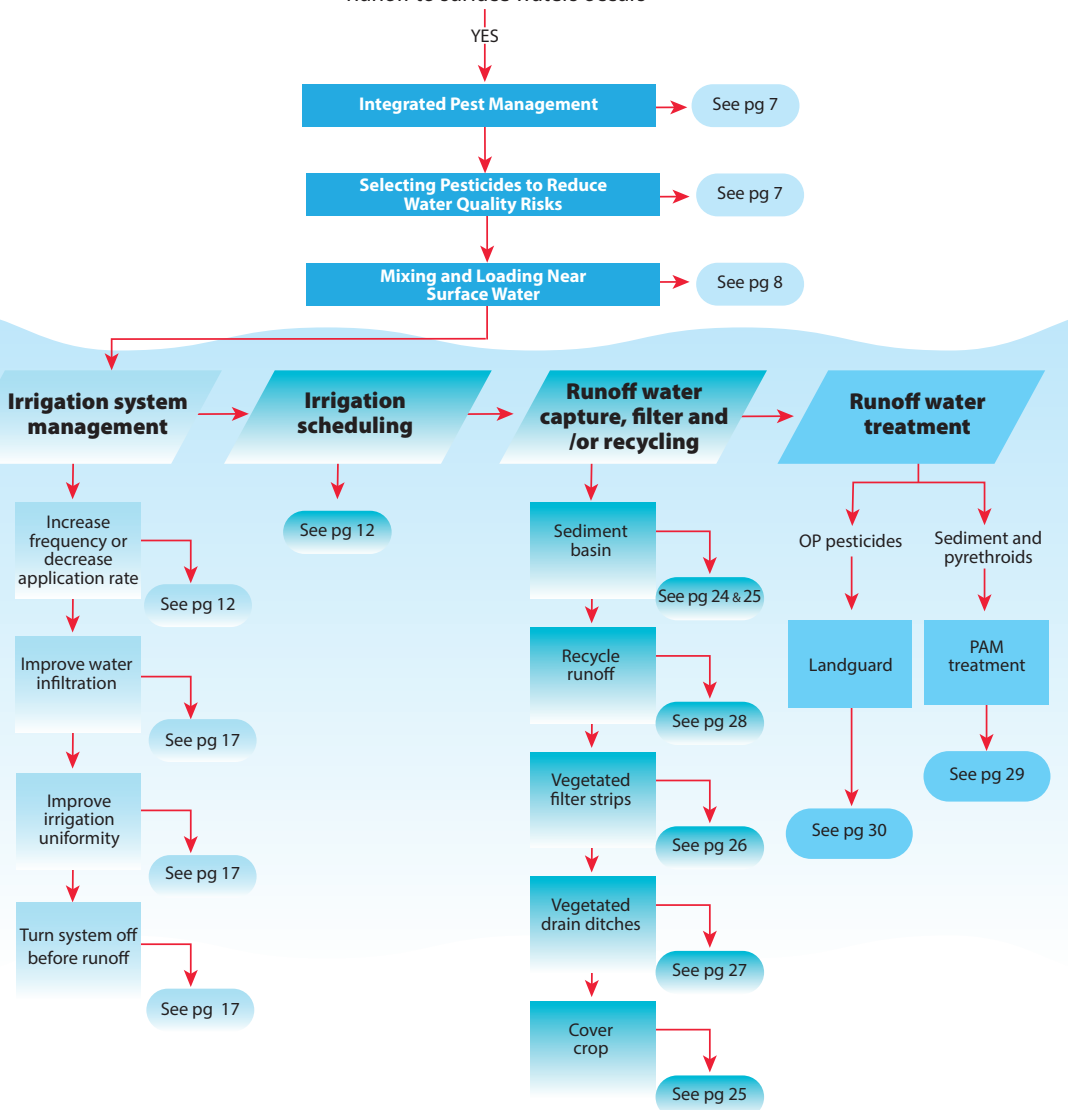

Figure 1. Excerpt from Flowchart 1 showing irrigation runoff risk for sample

Figure 2. Excerpt from Flowchart 2 showing pressurized irrigation runoff risk. 


\section{Management Practices that Reduce Surface Water Pesticide Contamination}

\section{Integrated Pest Management}

The University of California Integrated Pest Management Program's website, ucipm.ucdavis.edu, defines IPM as

an ecosystem-based strategy that focuses on long-term prevention of pests or their damage through a combination of techniques such as biological control, habitat manipulation, modification of cultural practices, and use of resistant varieties. Pesticides are used only after monitoring indicates they are needed according to established guidelines, and treatments are made with the goal of removing only the target organism. Pest control materials are selected and applied in a manner that minimizes risks to human health, beneficial and non-target organisms, and the environment.

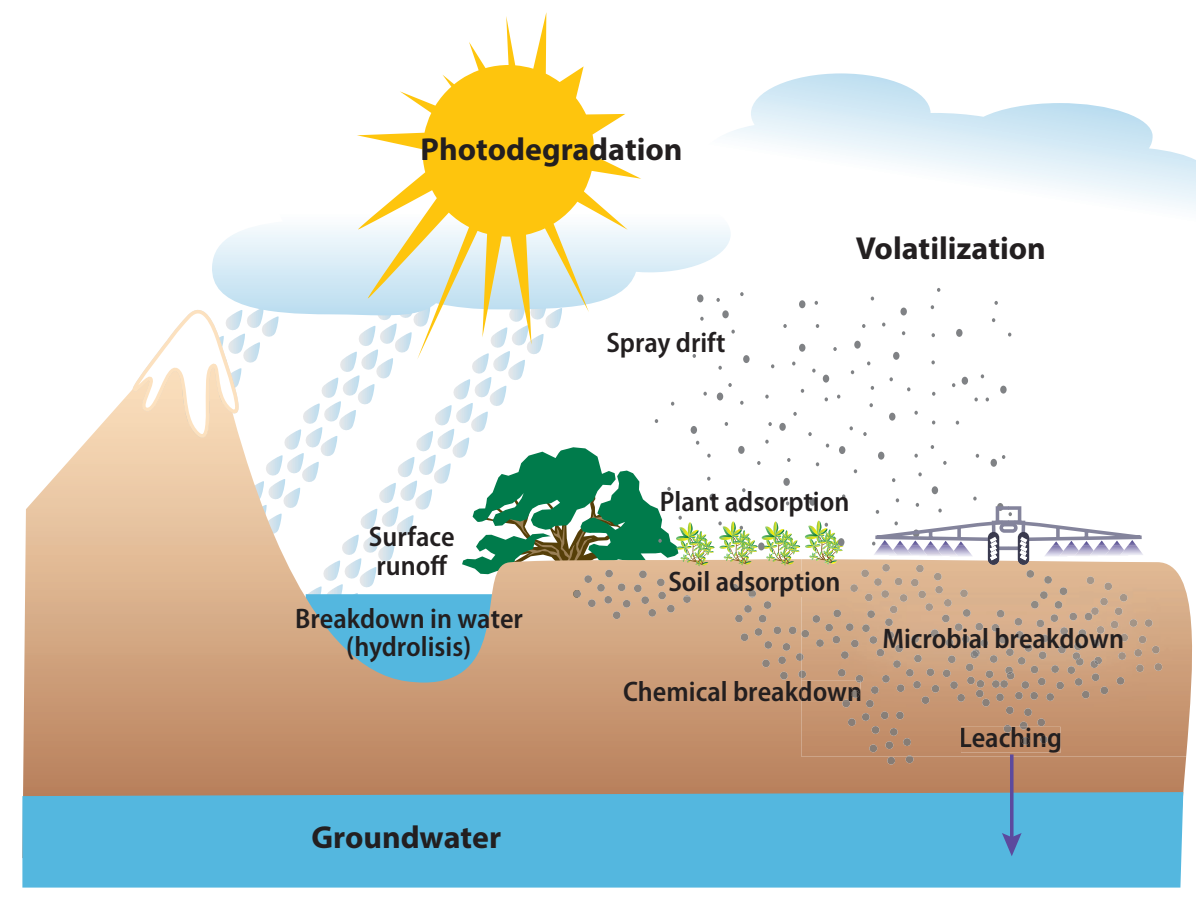

Figure 3. Pesticide movement and degradation.
IPM is a systematic approach to pest management. The decision process includes

- identifying the pest accurately

- understanding pest life cycles and conditions conducive to infestation

- monitoring for the presence, locations, and abundance of pests and their natural enemies

- treating when established action thresholds (economic, aesthetic, tolerance) are reached

- considering multiple tactics for pest suppression (biological, cultural, and chemical) and selecting the lowest-risk practical and effective approach

- evaluating results

For more information on walnut orchard IPM management actions, see

- The UC IPM Guidelines for Walnuts,

- ipm.ucdavis.edu/PMG/selectnewpest.walnuts.html

- The UC IPM Year Round Program for walnuts, with annual checklist, ipm.ucdavis.edu/PMG/C881/m881yi01.html

- Integrated Pest Management for Walnut (Strand 2003)

- Walnut Production Manual (Ramos 1998)

- licensed pest control and crop advisers

- UC IPM advisors and farm advisors

\section{Selecting Pesticides That Reduce Water Quality Risks}

Knowledge of how pesticides move and degrade in the environment is useful for selecting the best product to use. Pesticides and pesticide residues can move out of orchards along several different pathways, depending on the properties of the pesticide, the application method, and conditions at the application site (fig. 3). This movement is a complex process that, combined with several other factors, influences a pesticide's fate and potential water quality impacts. From a surface water management perspective, keeping the pesticide on or in the soil by preventing runoff is the most desirable option. 
Table 2. Insecticides registered for use on walnut in California (2011), their potential to move in solution or as adsorbed particles, and their overall pesticide runoff risk

\begin{tabular}{|c|c|c|c|c|c|}
\hline $\begin{array}{l}\text { Insecticide } \\
\text { active ingredient } \\
\text { (common name) }\end{array}$ & $\begin{array}{l}\text { Trade } \\
\text { name }\end{array}$ & Chemical class & $\begin{array}{l}\text { Solution } \\
\text { runoff } \\
\text { potential* }^{*}\end{array}$ & $\begin{array}{l}\text { Adsorption } \\
\text { runoff } \\
\text { potential }^{\dagger}\end{array}$ & $\begin{array}{l}\text { Overall } \\
\text { runoff risk }\end{array}$ \\
\hline bifenthrin & Brigade & pyrethroid & low & high & high \\
\hline carbaryl & Sevin & carbamate & intermediate & low & moderate \\
\hline chlorpyrifos & Lorsban & organophosphate & high & intermediate & very high \\
\hline diazinon & Diazinon & organophosphate & high & high & very high \\
\hline dicofol & Kelthane & organochlorine & high & high & high \\
\hline diflubenzuron & Dimilin & benzoylurea & & & \\
\hline esfenvalerate & Asana XL & pyrethroid & low & high & high \\
\hline hexythiazox & Savy & thiazolidine & high & intermediate & moderate \\
\hline imidacloprid & Provado & neonicotinoid & high & intermediate & low \\
\hline lamda-cyhalothrin & Warrior & pyrethroid & low & intermediate & high \\
\hline malathion & Malathion & organophosphate & intermediate & low & moderate \\
\hline methidathion & Supracide & organochlorine & Intermediate & low & moderate \\
\hline methyl parathion & Penn-Cap & organophosphate & intermediate & intermediate & moderate \\
\hline methyoxfenozoide & Intrepid & diacylhydrazine & & & \\
\hline permethrin & Pounce & pyrethroid & low & high & high \\
\hline phosmet & Imidan & organophosphate & intermediate & low & moderate \\
\hline propargite & Omite & organosulfur & high & high & high \\
\hline pyriproxyfen & Esteem & pyridine & unlisted & & \\
\hline spinetoram & Delegate & spinosyn & & & \\
\hline spinosad & Entrust & spinosyn & intermediate & intermediate & low \\
\hline spirodiclofen & Endivor & keto-enol & & & \\
\hline spirotetramat & Movento & keto-enol & intermediate & intermediate & low \\
\hline
\end{tabular}

Source: Long et al. 2005

Notes:

"Likelihood that the active ingredient will transport from the area of treatment as dissolved chemical in runoff.

tLikelihood that the active ingredient will transport from the area of treatment as attachment to soil or sediment particles in runoff.

sOverall likelihood to cause negative impact on surface water quality as a product of the runoff potential and the aquatic toxicity of the pesticide
Active ingredients in pesticides used on walnut vary in their water solubility, soil adsorption, and half-life. Pesticides with high water solubility can move directly in runoff water, while those adsorbed to soil sediments (which generally have low water solubility) move with the sediment. Half-life is an indication of the pesticide's persistence in the environment, and it is usually measured in the number of days it takes for the pesticide to degrade to one half its original concentration. The soil adsorption coefficient $\left(\mathrm{K}_{\mathrm{oc}}\right)$ can be considered an index of pesticide mobility. The USDA Natural Resources Conservation Service has a model (WIN-PST) that takes these characteristics into consideration in determining a pesticide's tendency to move in dissolved form with water or to move while adsorbed to sediments. A pesticide's potential to move offsite, either in solution or with the soil, is categorized as high, intermediate, or low (table 2).

A pesticide's overall likelihood (risk) to cause a negative impact on surface water quality is a product of its runoff potential and the aquatic toxicity of the pesticide (table 2). Runoff potential depends on the water solubility of the pesticide and its potential for adsorption to soil particles transported by runoff water. The aquatic toxicity rankings used to characterize the risks in table 2 were extracted from the U.S. EPA ECOTOX database (EPA 2007) and toxicity to certain U.S. EPA indicator species. (Long et al. 2005). The table can be used to select pesticides based on the risk of offsite movement to surface water. Changing from one pesticide to another in the same class or in a different class can significantly reduce the environmental risk of offsite movement.

\section{Pesticide Handling Practices That Reduce Water Quality Risks}

The risk of offsite pesticide movement is great during mixing and loading due to the possible spillage of undiluted pesticides. Care must be taken to ensure that all of the pesticide goes in the tank. Partially fill the tank with water prior to adding the pesticide to prevent high-strength materials from entering spray lines. Agitation and the use of a bypass can assist good mixing. Avoid overfilling the tank, because spillage can move offsite aided by cleanup water. Mix and load farther than 50 feet from sensitive areas (e.g., open surface 
water). Use a greater distance if there is a potential for movement in the direction of the sensitive area. Triple-rinse pesticide containers and pour the rinsate into the sprayer tank for use on the orchard. Also apply tank rinse water to the orchard. Using a concrete mixing and loading pad with a catchment sump is another good way to reduce risks from mixing and loading near surface water sources.

\section{Minimizing Spray Drift}

Drift is the physical movement of pesticide droplets or particles through the air from the target site to any off-target site at or shortly after the time of application. All ground and aerial applications produce some drift. How much drift occurs depends on the formulation of the material applied, how the material is applied, the volume of spray solution used, prevailing weather conditions at the time of application, and the size of the application area. Drift can impact surface water quality through direct contact with empty or water-filled ditches or other water bodies near the treated field.

Application practices that take weather and other site conditions into consideration have appropriately equipped delivery systems (low-drift nozzles) and use appropriate product choice (low vapor pressure and low water solubility), and using buffer zones can significantly reduce the risk of offsite movement of pesticides. Specific examples and suggestions for walnuts include:

\section{Application conditions}

- Do not apply pesticides under dead calm conditions, where drift can easily migrate, or in windy or gusty conditions; do not apply at wind speeds greater than $10 \mathrm{mph}$ (ideally not over $5 \mathrm{mph}$ ). Read the label for specific instructions.

- Apply pesticides early in the morning or late in the evening, when the air is usually calmer than during the day.

- Determine the wind direction and take it into account when deciding whether or how to make an application.

- Calibrate and adjust sprayers to accurately direct the spray into the canopy target.

- Delay treatments near ditches and surface water until the wind is blowing away from these and other sensitive areas.
- Do not spray during thermal inversions, when air closest to the ground is warmer than the air above it.

\section{Application equipment}

- Use the coarsest spray possible (250 to 400 microns or larger) while still obtaining good coverage and control. Droplet size is one of the most important factors affecting drift: the larger the droplet, the less drift.

- Use low-drift nozzles that produce larger droplets. Fitting a sprayer with air induction nozzles reduces spray drift up to $50 \%$ over standard nozzles.

- Verify that the expected spray pattern is being deposited.

- Service and calibrate spray equipment regularly.

- Check the system for leaks. Small leaks under pressure can produce very fine droplets. Large leaks contaminate soil that can be moved offsite by water.

- Use low pressure and spray volumes appropriate for the canopy size.

\section{Product choice}

- Choose an application method and formulation that are less likely to cause drift. After considering the drift potential of a product, formulation, or application method, it may become necessary to use a different product to reduce the chance of drift.

- Use drift control or drift reduction spray additives. These materials are generally thickeners designed to minimize the formation of droplets smaller than 150 microns. They also help produce a more consistent spray pattern and deposition.

- Use spray adjuvants, which can greatly reduce application volumes without compromising pesticide efficacy.

- Use the maximum spray volume per acre and low pressure.

\section{Buffer zones}

- Maintain adequate buffer zones around the treated site to ensure that pesticides do not drift onto sensitive areas. A buffer zone is the area between the waterway and where the pesticide is applied. Read the label to determine the size of buffer zone required as related to the active ingredient. 
- Treat buffer zones with materials that pose the least risk to aquatic life.

- Change application method. Aerial application has a larger drift potential than ground application. When the risk of drift risk is present, changing to ground application requires a smaller buffer zone.

Avoiding Application Times Prone to Risk

Avoid applications when rain is predicted, especially when the soil is saturated by previous rainfall. Also, pesticides that require application after harvest are at risk of residue runoff when applied to saturated soil or when rainfall is predicted.

\section{Irrigation Water Management Practices That Reduce Runoff}

Proper irrigation management includes or involves assessing crop water needs and applying irrigation water to supplement stored winter moisture. Irrigation frequency and duration should ensure that enough water infiltrates to meet plant water needs while preventing water loss through runoff and deep percolation. The extent of runoff depends on several factors, including the slope or grade of an area, the texture and moisture content of the soil, its infiltration rate, and the amount and timing of irrigation or rainfall.

\section{Walnut Orchard Irrigation Systems}

Two basic types of irrigation systems are used in walnut production: surface systems (furrow, or border-check), and pressurized systems (sprinklers and microirrigation). Each has distinct cultural, cost, and offsite movement advantages and disadvantages. However, some disadvantages can be overcome using specific management practices.

\section{Surface irrigation systems}

Surface irrigation systems such as flood, border-check, and furrow irrigation, (fig. 4) while being the simplest irrigation systems with regard to hardware, are the most difficult to manage properly. Control of runoff water is essential for controlling offsite movement of pesticides, sediments, and nutrients.

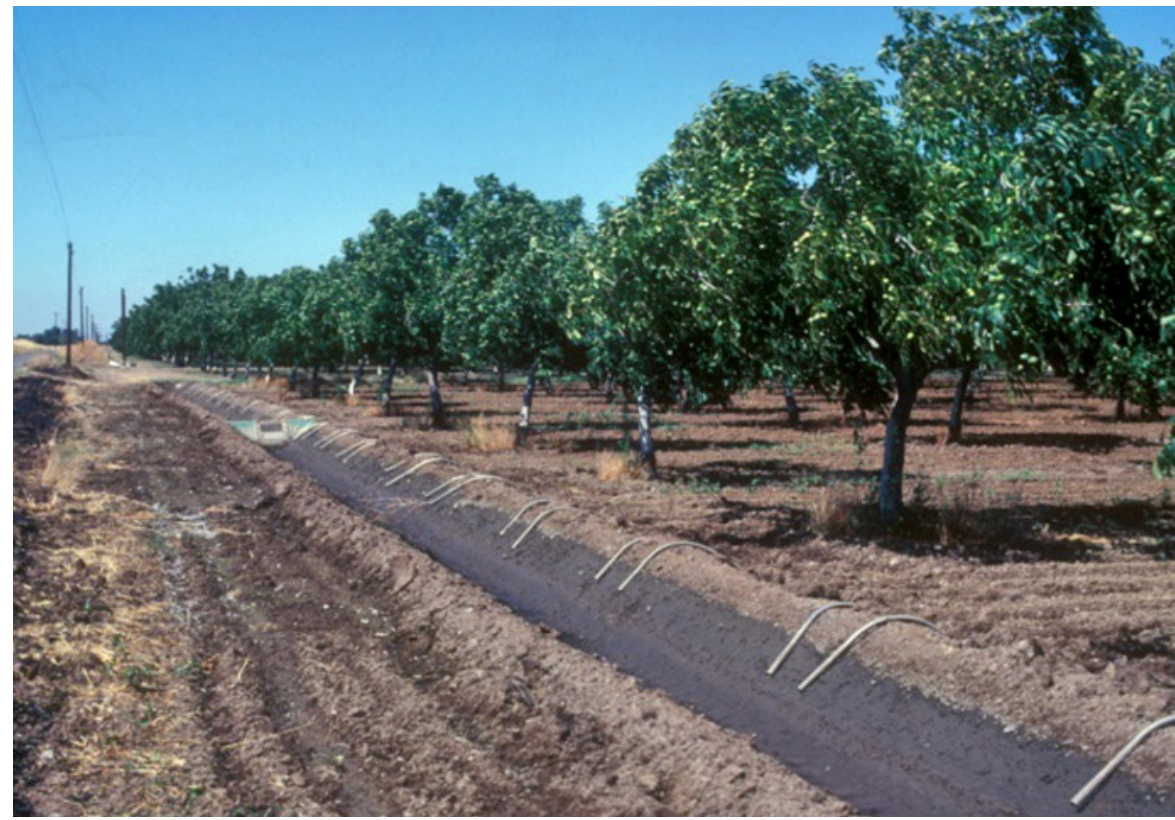

Figure 4. Furrow irrigation in a walnut orchard. Photo: L. Schwankl

With surface systems, water is applied to the soil surface and gravity moves the water across the orchard. Soil characteristics control both the rate at which water enters the soil and its distribution across the irrigated area. As irrigation begins, the rate at which water enters the soil is high, primarily because of soil dryness and easy access to the soil pores. As irrigation proceeds, the infiltration rate declines rapidly to a sustained rate (also called basic rate). Figure 5 shows the typical relationship between the amount of water infiltrated into the soil and hours of irrigation.

A soil's water intake characteristics depend on its physical and chemical composition as well as the chemical composition of the water. Irrigation water with very low salt content or high levels of sodium or bicarbonate can reduce infiltration rates. For more information, see "Reducing Runoff by Improving Water Infiltration," below. 
Figure 5. Typical water infiltration characteristics in surface irrigation.

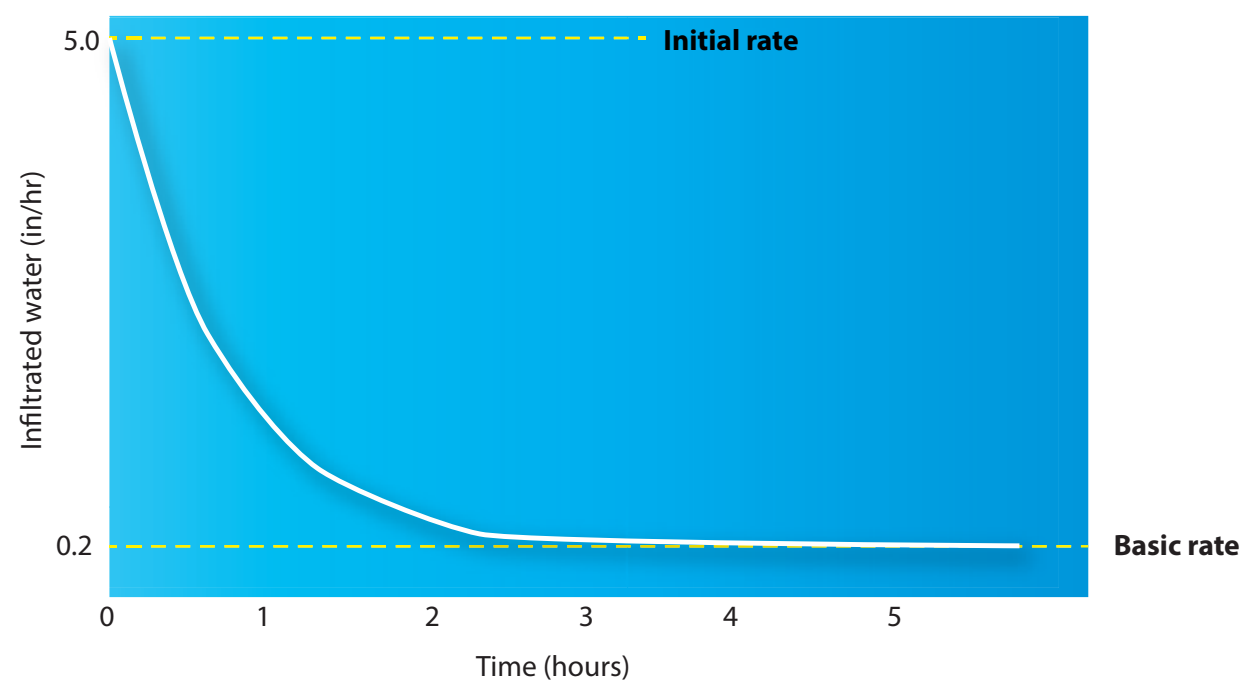

In general, the objective of any irrigation system is to have water infiltrating for the same length of time in all parts of the field. This is difficult to accomplish with border check systems because it takes time for water to flow from the head of field down to the tail of the field. This "advance time" causes less water to be infiltrated toward the tail of the field.

For surface irrigation, the head of the orchard irrigation run almost always has more water applied to it than the tail of the run. The exception is if water is allowed to pond at the end of the row. The part of the field that gets the least water applied to it is frequently at approximately two-thirds to three-fourths of the distance down the row. Often, irrigators increase the water onflow rate to the furrow or check is to get water down the row more quickly and improve irrigation uniformity. Unfortunately, this practice increases the runoff volume.

In general, keeping furrows or checks as short as practical helps keep irrigation uniformity high. The tradeoff with short furrows or checks is that labor and pipeline costs increase, as does runoff volume. Tailwater return systems can increase the efficiency of these systems and eliminate discharges. Limiting runoff after a reasonable uniformity has been achieved is an effective practice to reduce the continued movement of residues offsite. An irrigation runoff return or tailwater return system can capture runoff and return it to the irrigation inflow, to be applied to adjacent irrigation sets or another field. At sites with runoff risks to surface water, changing from surface irrigation to pressurized irrigation is recommended when possible.

\section{MEASURING APPLIED WATER IN SURFACE SYSTEMS}

One difficulty in managing surface irrigation systems is measuring the volume of water applied to the field. If water is supplied from a pump, a flow meter such as a propeller meter can be installed in the outlet pipe. Follow the manufacturer's recommended installation criteria to obtain accurate measurements. It is difficult to measure water supplied from an open ditch. Consult the irrigation district for help in getting a good estimate of the flow rate to the field.

Use the following formula to determine the average volume of water applied to a field using a meter that indicates cubic feet per second $(\mathrm{cfs})$ :

$$
D=Q \times T \div A,
$$

where $D=$ depth of applied water (inches), $Q=$ flow rate into the field (cubic feet per second), $T=$ time required to apply water to 


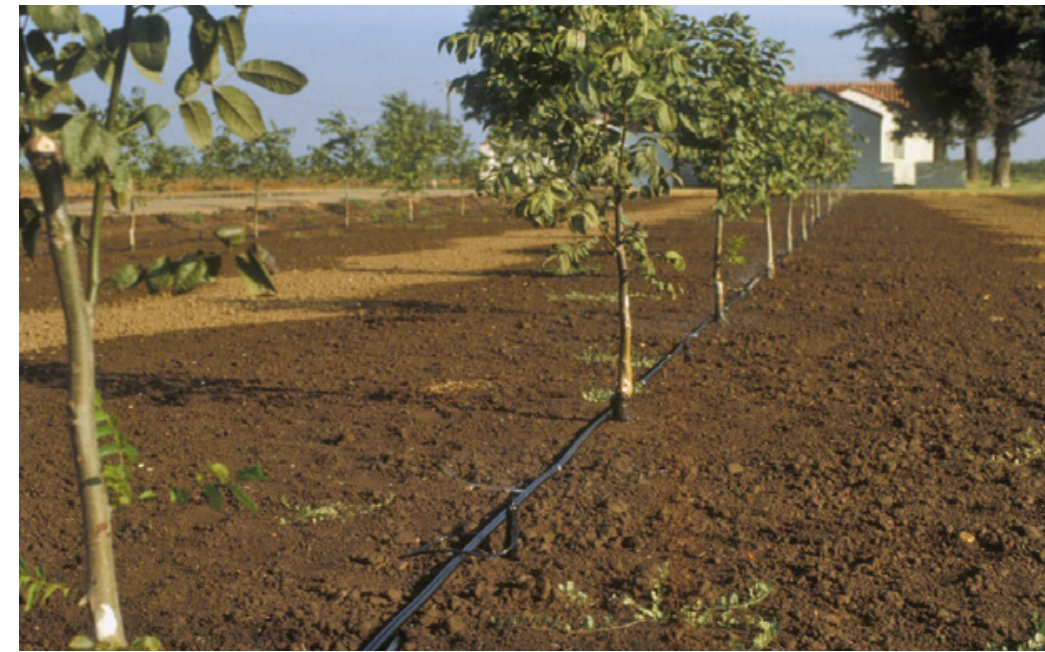

Figure 6. Pressurized irrigation in a walnut orchard. Photo: L. Schwankl

the field (hours), and $A=$ acres irrigated. If the flow meter reads in gallons per minute (gpm) rather than in cubic feet per second, the conversion is $1 \mathrm{cfs}=449 \mathrm{gpm}$. For example, assume that flow $=4.45$ cfs $(2,000 \mathrm{gpm})$, irrigation duration $=8.6$ hours, and area $=8$ acres:

$$
\begin{gathered}
D=4.45 \mathrm{cfs} \times 8.6 \mathrm{hr} \div 8 \mathrm{ac} \\
=4.8 \text { inches }
\end{gathered}
$$

The depth of water obtained in the above formula should match the amount of water used by the crop since the last irrigation, which is roughly equivalent to evapotranspiration (ET) (see "Irrigation Scheduling to Meet Crop Requirements," below). Remember that some additional water should be applied because no irrigation system is $100 \%$ efficient; border check irrigation is generally less efficient than pressurized irrigation.

Measuring the distribution of infiltrated water under surface systems is difficult at best. The overall goal is to provide near-equal opportunity time along the length of the furrow.

\section{Pressurized irrigation systems}

Pressurized orchard irrigation includes sprinkler and buried or surface drip systems. Sprinklers that can wet the entire orchard floor are often called full-coverage sprinklers, and those that can wet part of the orchard are called micro sprinklers. Drip systems allow small amounts of water to be applied slowly and frequently through emitters spaced along polyethylene tubing (fig. 6). When properly designed and operated, drip systems apply water uniformly to a relatively small volume of soil.

To prevent runoff in pressurized irrigation systems, water should be applied at a slower rate than it is absorbed by the soil (the infiltration rate). However, as irrigation progresses, the risk of runoff increases because infiltration rate declines over time. To prevent runoff, the system should be turned off before significant runoff occurs. When properly managed, runoff in pressurized irrigation systems is eliminated, effectively reducing the risk of pesticide moving offsite.

Unlike surface irrigation systems or full coverage sprinklers, where soil-water is recharged on an infrequent basis and then drawn down by tree use, microirrigation, by virtue of frequent applications, can be operated to more quickly replace water used by the tree. The process occurs on a time scale of a few days.

\section{Irrigation Scheduling to Meet Orchard Water Requirements}

Walnut orchards use soil-stored winter rainfall and irrigation water to meet their demands for water. Water use begins at a low level as trees leaf-out in spring when climatic conditions are mild, then gradually increases as the canopy develops, days lengthen, and the weather warms. Water use reaches a peak in midsummer, then decreases as fall approaches and stops when leaves drop.

Crop water use or evapotranspiration (ET) is the sum of plant water use (transpiration) and evaporation from the soil surface. Climate factors affecting the crop evapotranspiration include solar radiation, temperature, wind, and humidity. Plant and soil factors affecting evapotranspiration include plant type, canopy size, health of the plant, and available soil moisture.

\section{Irrigations should}

- be applied to meet the variable crop requirements over the season

- be distributed evenly to maximize irrigation efficiency and facilitate the uptake of nutrients 
- minimize saturated soil conditions that encourage diseases and result in excess runoff

Some water in excess of the crop requirement may be needed to maintain a favorable salt balance in the root zone.

\section{Estimating orchard water requirements}

The best way to determine an orchard's irrigation requirement is to estimate the volume of water consumed by the orchard using climatic data and the orchard's specific characteristics. Walnut orchard ET can be estimated using the following formula:

$$
\mathrm{ET}_{\mathrm{c}}=\mathrm{ET}_{\mathrm{o}} \times \mathrm{K}_{\mathrm{c}}
$$

Where $\mathrm{ET}_{\mathrm{c}}$ is the crop water use, $\mathrm{ET}_{\mathrm{o}}$ is the reference evapotranspiration for a given area, and $\mathrm{K}_{\mathrm{c}}$ is a crop coefficient.

$\mathrm{ET}_{\mathrm{c}}$ in inches of water can be time-framed to the day, week, month, or season in order to assess the orchard's water requirements for irrigation scheduling purposes. Reference ET information is available from a network of nearly 100 California weather stations that provide daily reference evapotranspiration values.

This information is made available to growers through the CIMIS program managed by the California Department of Water Resources, www.cimis.water.ca.gov/cimis. Another webbased source for $\mathrm{ET}_{0}$ is the UC Statewide Integrated Pest Management website, www.ipm.ucdavis.edu. Also, some newspapers and irrigation districts provide CIMIS $\mathrm{ET}_{\mathrm{o}}$ data. The CIMIS program provides real-time current values. Historical or long-term average $\mathrm{ET}_{\mathrm{o}}$ can be more convenient than real-time $\mathrm{ET}_{\mathrm{o}}$ information and can be used to prepare an irrigation plan ahead for the irrigation season. Table 3 lists historical daily $\mathrm{ET}_{0}$ values for selected Central Valley locations.

The crop coefficient $(\mathrm{Kc})$ is used with ETo to estimate ETc in a mature orchard that is not water stressed. An orchard is considered to be mature when about $62 \%$ or more of the orchard floor is shaded at midday. The Kc for walnut has been experimentally determined for various times through the growing season. Table 4 shows the calculations for determining mature walnut orchard water use, in 2-week periods, from leaf-out to leaf drop using the reference ETo from the CIMIS station 70 located near Manteca, California. Historical ETo daily and summed values for different time scales are available for the Manteca (\#70 and Lodi \#166) CIMIS stations based on the past 20 years of data at ucanr.org/sites/CE_San_Joaquin/Custom_Program/Publications_Available_for_Download/. Monthly averages from all CIMIS stations are available at the CIMIS web site, www.cimis.water.ca.gov.
Table 3. Historical crop evapotranspiration reference (in/day) for various California Central Valley locations

\begin{tabular}{|c|c|c|c|c|c|}
\hline \multicolumn{2}{|c|}{ Date } & Hanford & Manteca & Davis & Durham \\
\hline \multirow{2}{*}{ Jan } & $1-15$ & 0.04 & 0.04 & 0.03 & 0.03 \\
\hline & $16-31$ & 0.05 & 0.05 & 0.05 & 0.05 \\
\hline \multirow{2}{*}{ Feb } & $1-15$ & 0.06 & 0.07 & 0.06 & 0.06 \\
\hline & $16-28$ & 0.09 & 0.09 & 0.09 & 0.09 \\
\hline \multirow{2}{*}{ Mar } & $1-15$ & 0.11 & 0.11 & 0.09 & 0.09 \\
\hline & $16-31$ & 0.15 & 0.14 & 0.14 & 0.12 \\
\hline \multirow{2}{*}{ Apr } & $1-15$ & 0.20 & 0.17 & 0.18 & 0.16 \\
\hline & $16-30$ & 0.22 & 0.19 & 0.28 & 0.17 \\
\hline \multirow{2}{*}{ May } & $1-15$ & 0.23 & 0.22 & 0.23 & 0.21 \\
\hline & $16-31$ & 0.27 & 0.23 & 0.24 & 0.22 \\
\hline \multirow{2}{*}{ Jun } & $1-15$ & 0.29 & 0.26 & 0.28 & 0.25 \\
\hline & $16-30$ & 0.30 & 0.27 & 0.29 & 0.26 \\
\hline \multirow{2}{*}{ Jul } & $1-15$ & 0.30 & 0.27 & 0.29 & 0.27 \\
\hline & $16-31$ & 0.28 & 0.25 & 0.27 & 0.25 \\
\hline \multirow{2}{*}{ Aug } & $1-15$ & 0.28 & 0.24 & 0.26 & 0.24 \\
\hline & $16-31$ & 0.25 & 0.22 & 0.24 & 0.21 \\
\hline \multirow{2}{*}{ Sep } & $1-15$ & 0.23 & 0.19 & 0.21 & 0.19 \\
\hline & $16-30$ & 0.20 & 0.16 & 0.18 & 0.16 \\
\hline \multirow{2}{*}{ Oct } & $1-15$ & 0.17 & 0.13 & 0.16 & 0.14 \\
\hline & $16-31$ & 0.13 & 0.10 & 0.12 & 0.10 \\
\hline \multirow{2}{*}{ Nov } & $1-15$ & 0.10 & 0.07 & 0.09 & 0.07 \\
\hline & $16-30$ & 0.07 & 0.05 & 0.06 & 0.05 \\
\hline \multirow{2}{*}{ Dec } & $1-15$ & 0.05 & 0.04 & 0.05 & 0.04 \\
\hline & $16-31$ & 0.03 & 0.04 & 0.04 & 0.03 \\
\hline
\end{tabular}

Table 4. Irrigation scheduling using ETo values based on a 20-year average, Manteca, CIMIS Station 70; leaf-out 3/15, leaf drop 11/15, no cover crop

\begin{tabular}{|c|c|c|c|c|}
\hline Date & $\begin{array}{l}\text { Evapotranspiration } \\
\text { reference } \\
\left(\mathrm{ET}_{\mathrm{o}}\right)\end{array}$ & $\begin{array}{l}\text { Crop } \\
\text { coefficient } \\
\left(K_{c}\right)\end{array}$ & $\begin{array}{l}\text { Water use } \\
\text { (inches, } \mathrm{ET}_{\mathrm{c}} \text { ) }\end{array}$ & $\begin{array}{l}\text { Cumulative } \\
\text { inches } \\
\text { (ET) }\end{array}$ \\
\hline Mar 16-31 & 2.3 & 0.12 & 0.28 & 0.3 \\
\hline Apr 1-15 & 2.5 & 0.53 & 1.34 & 1.6 \\
\hline Apr 16-30 & 2.9 & 0.68 & 1.96 & 3.6 \\
\hline May $1-15$ & 3.3 & 0.79 & 2.59 & 6.2 \\
\hline May $16-31$ & 3.6 & 0.86 & 3.14 & 9.3 \\
\hline Jun 1-15 & 3.8 & 0.93 & 3.53 & 12.8 \\
\hline Jun 16-30 & 4.0 & 1.00 & 3.98 & 16.8 \\
\hline Jul 1-15 & 4.1 & 1.14 & 4.66 & 21.5 \\
\hline Jul 16-31 & 3.9 & 1.14 & 4.49 & 26.0 \\
\hline Aug 1-15 & 3.7 & 1.14 & 4.16 & 30.1 \\
\hline Aug 16-31 & 3.5 & 1.14 & 3.98 & 34.1 \\
\hline Sep 1-15 & 2.9 & 1.08 & 3.12 & 37.2 \\
\hline Sep 16-30 & 2.4 & 0.97 & 2.30 & 39.5 \\
\hline Oct 1-15 & 2.0 & 0.88 & 1.73 & 41.3 \\
\hline Oct 16-31 & 1.6 & 0.51 & 0.79 & 42.1 \\
\hline Nov $1-15$ & 1.1 & 0.28 & 0.30 & 42.4 \\
\hline
\end{tabular}


Generally, cover crops in orchards use water in the winter and before leaf-out. Their water use during this time, if in excess of rainfall, decreases the amount of water in storage at leaf out. Cover crops grown during the tree growing season, if extensive in coverage, can increase water use about $25 \%$ over the values in table 4 .

Young trees, those with less than $62 \%$ shaded orchard floor measured at midday, are generally better irrigated using soil-based monitoring. Monitoring soil moisture can often be more critical in young trees than in a mature orchard due to the greater potential for excessive soil-water saturation, leading to root disorders.

\section{Determining the irrigation amount}

Once the crop water requirement has been determined for a period of time (bi-weekly, in table 4), the demand can be met by different sources of water. Water can be available from stored soil moisture, effective in-season rainfall, or as applied irrigation.

If rainfall occurs that increases the soil water content (called effective rainfall) during these periods, it must be subtracted from the $\mathrm{ET}_{\mathcal{c}}$, effectively reducing the irrigation requirement. Most irrigators feel that, for rainfall to be effective, it must occur in a quantity that exceeds the daily reference $\mathrm{ET}_{\mathrm{o}}$ by a factor of three. For example, a rainstorm on April 25 would have to provide 0.6 inch $f$ water to exceed the ETo average of 0.2 inch for that date. The method used to approximate the effective in-season rainfall in this case is

inches of rainfall $-0.6=$ inches of effective rainfall.

Soil storage plays an important role in the seasonal irrigation requirement. Soils hold stored water at leaf-out for subsequent tree use. The amount of winter rainfall stored for subsequent tree use is generally about one-half the total winter rainfall if the water-holding capacity of the root zone is large enough to hold that amount. When soil storage is full, the amount varies primarily by soil texture and root zone depth. Table 5 shows the available soil moisture in inches of water per foot of soil for various soil textures. To estimate the available soil water, multiply This amount of water (inches per foot of soil) is multiplied times the root zone depth in feet. About onehalf of this value is easily available before tree stress begins. This
Table 5. Available soil moisture content in inches of water per foot of soil for various soil textures

\begin{tabular}{|l|c|}
\hline Soil texture & $\begin{array}{c}\text { Available } \\
\text { moisture } \\
\text { content }\end{array}$ \\
\hline sand & 0.7 \\
\hline loamy sand & 1.1 \\
\hline sandy clay loam & 1.3 \\
\hline sandy loam & 1.4 \\
\hline sandy clay & 1.6 \\
\hline clay loam & 1.6 \\
\hline loam & 1.8 \\
\hline silt loam & 1.8 \\
\hline silty clay loam & 1.9 \\
\hline clay & 2.2 \\
\hline silty clay & 2.4 \\
\hline
\end{tabular}

Table 6. Estimated application efficiency (percent) of irrigation systems

\begin{tabular}{|l|c|}
\hline System type & Estimated efficiency \\
\hline surface irrigation & $60-80^{*}$ \\
\hline sprinkler & $70-85$ \\
\hline micro-irrigation & $85-90$ \\
\hline
\end{tabular}

Source: Hanson 1995.

Note: *Efficiency reflects the use of a tailwater capture and return system. If not available, reduce by $15 \%$.

value (one-half the available moisture content) can be subtracted from the seasonal use when calculating the net irrigation amount for the season. The importance of the amount of soil moisture in irrigation scheduling diminishes as midsummer is reached, since a substantial portion has been consumed, allowing scheduling to occur based on $\mathrm{ET}_{\mathrm{c}}$ alone.

Once the orchard net irrigation requirement has been determined, the irrigator must account for losses such as evaporation, runoff, and deep percolation. These losses depend on the type of irrigation system and its management. Surface irrigation (border check and furrow) can have substantial runoff losses and has larger variability in infiltration than do pressurized systems. This variability in infiltration requires that additional water be applied to supply a minimum amount of water to all parts of the orchard. Sprinkler irrigation systems have greater application uniformity, less deep percolative losses, and little if any runoff compared with surface systems. Drip and microsprinkler systems have the advantages of sprinkler systems and also have less evaporative losses. To account for these differences between systems, we use the term irrigation efficiency (table 6 to adjust the applied irrigation water amount to meet the orchard water requirement. 
To adjust the application amount for system efficiency, divide the net amount to be applied by the system efficiency factor. For example, to supply 2.7 inches of water to a sprinkler-irrigated orchard that has an irrigation efficiency of $75 \%$,

$$
2.7 \times 0.75=3.6 \text { inches of water }
$$

must be applied to the orchard. This amount is called the gross irrigation application, which ensures that adequate water is applied to the areas of the orchard receiving the least water.

\section{Determining irrigation on-time (duration)}

The irrigation application duration for a surface irrigation system is determined by dividing the amount of water applied by the land area it is applied to:

$$
\mathrm{T}=(\mathrm{A} \times \mathrm{D}) \div \mathrm{Q}
$$

where $\mathrm{T}=$ duration of irrigation (hours), $\mathrm{A}=$ acres irrigated, $\mathrm{D}=$ depth of applied water (inches), and $\mathrm{Q}=$ flow rate into the field (cfs; $1 \mathrm{cfs}=$ 449 gallons per minute).

\section{Example:}

\section{FURROW AND BORDER-CHECK IRRIGATION}

Using an example of 4.0 inches $\mathrm{ET}_{\mathrm{c}}$ for a 2 -week period in June (table 4), an efficiency of $75 \%$ in a tailwater recovery system, and a 20 -acre field with a water supply of 1,200 gallons per minute supply, or 2.7 cubic feet per second $(1,200 \mathrm{gal} / \mathrm{min} \div 449 \mathrm{gal} / \mathrm{cfs}=2.7 \mathrm{cfs})$, the irrigation duration would be:

$$
\mathrm{T}=(20 \times 3.6) \div 2.7=27 \mathrm{hr}
$$

\section{Example:}

\section{SPRINKLER AND DRIP IRRIGATION}

To determine the irrigation time for sprinklers,

$$
\mathrm{T}=\mathrm{D} \div \mathrm{AR}
$$

Where $\mathrm{T}=$ duration of irrigation (hours), $\mathrm{D}=$ depth of water (inches), and $\mathrm{AR}=$ application rate (inches/hour).

Using our example for a 1-week net irrigation in the last half of June, the gross applied water is 2.7 inches and the application rate is 0.10 inch per hour. The duration would be

$$
\mathrm{T}=2.7 \div 0.10=27 \mathrm{hr}
$$

\section{Verifying calculations and applications}

The climate-based method described above for determining crop water needs gives an estimate of demand that should be verified and fine-tuned using soilbased monitoring of soil water status.

Many soil moisture monitoring devices measure soil moisture content and soil tension (Schwankl and Prichard 2009). If the soil-water content continues to decrease (or the soil-water tension increases) over the season, it is evident that too little irrigation was applied. If the soil-water content increases (or the soilwater tension declines) after each irrigation, too much water is being applied.

In contrast to soil-based methods, which assess how soil moisture responds to irrigation applications and tree water use, plant-based monitoring, performed using a pressure chamber to measure actual tree water status, allows for direct and timely assessments of tree water status, referred to as stem water potential (SWP), as it changes in relation to water applications and use. Research has shown that SWP readings are an accurate and reliable indicator of tree water status and can be used very effectively to fine-tune irrigation scheduling decisions and evaluate their impacts on orchard status. Table 7 summarizes tentative guidelines developed for interpreting pressure chamber readings in walnuts based on research trials.

Table 7. Tentative guidelines for interpreting pressure chamber readings (midday stem water potential, SWP) in walnut

\begin{tabular}{|l|l|}
\hline $\begin{array}{l}\text { Pressure chamber } \\
\text { reading (bar) }\end{array}$ & Interpretation guidelines \\
\hline 0 to -2.0 & Not commonly observed \\
\hline-2.0 to -4.0 & $\begin{array}{l}\text { Fully irrigated, low stress, commonly observed when orchards are irrigated } \\
\text { according to estimates of real time evapotranspiration (ETc), long term root and } \\
\text { tree health may be a concern }\end{array}$ \\
\hline-4.0 to -6.0 & $\begin{array}{l}\text { Low to mild stress, high rate of shoot growth visible, suggested level from leaf-out } \\
\text { until mid June when nut sizing is completed }\end{array}$ \\
\hline-6.0 to -8.0 & $\begin{array}{l}\text { Mild to moderate stress, shoot growth in non-bearing and bearing trees has been } \\
\text { observed to decline especially with Black Walnut Rootstock. These levels do not appear to } \\
\text { affect kernel development and may be appropriate during kernel development }\end{array}$ \\
\hline-8.0 to -10.0 & $\begin{array}{l}\text { Moderate to high stress, shoot growth in non-bearing trees may stop, nut sizing } \\
\text { may be reduced in bearing trees }\end{array}$ \\
\hline-10.0 to -12.0 & $\begin{array}{l}\text { High stress, temporary wilting of leaves has been observed. New shoot growth may be } \\
\text { sparse or absent and some defoliation may be evident. Nut size likely to be reduced. }\end{array}$ \\
\hline-12.0 to -14.0 & Relative high levels of stress, moderate to severe defoliation, should be avoided \\
\hline-14.0 to -18.0 & \begin{tabular}{l} 
Severe defoliation, trees are likely dying \\
\hline Source: Fulton et al., n.d. Note: For more information, see Schwankl and Prichard 2009b.
\end{tabular} \\
\hline
\end{tabular}




\section{Modifying irrigation systems and management}

Surface irrigation systems

Irrigation runoff that enters surface water can carry dissolved and sediment-adsorbed pesticide residues. Dissolved residue concentrations in runoff water are fairly consistent for the entire runoff period. Therefore, any reduction in the total runoff volume will reduce the amount of residues discharged. The movement of sediment-adsorbed pesticides depends on a number of factors, with soil aggregate stability (the ability of soil particles to cling together and resist the forces of flowing water) being the most important. Aggregate stability can be enhanced by chemical and physical amendments and management practices discussed in the section "Reducing Runoff by Improving Water Infiltration." Soil erosion rates also depend on the soil conditions, including the amount, size, and density of loose particles on the soil surface, the velocity of the water, and the duration of runoff. Therefore, reducing the peak volume and duration of runoff reduces sediment loss.

Irrigation inflow rates irrigation cutoff times should be chosen so as to to balance distribution uniformity and runoff. Higher flow rates reduce the advance time but can increase runoff volume. The cutoff time is a specific time after the irrigation begins when no more water is applied to the furrow or check, though the irrigation itself actually continues until water in the check has infiltrated or run off. The cutoff time for a given field depends on the time needed to infiltrate sufficient water in lower parts of the orchard, and is oftendetermined on a trialand-error basis.

In cracking clay soils, infiltration times of only 2 to 3 hours may be adequate because water flow into the cracks results in a very high initial infiltration rate. After the cracks close, infiltration rates become very low. Thus, as a general rule, the cutoff time in cracked soils should be about 2 to 3 hours after water reaches the end of the field (Hanson and Schwankl 1995). Figure 7 illustrates inflow and outflow rates in a field using furrow irrigation. Note that 700 minutes of water must be applied to the furrow to advance water to field end (before runoff begins), and a nearly equal time must be allowed for the irrigation to have equal intake opportunity

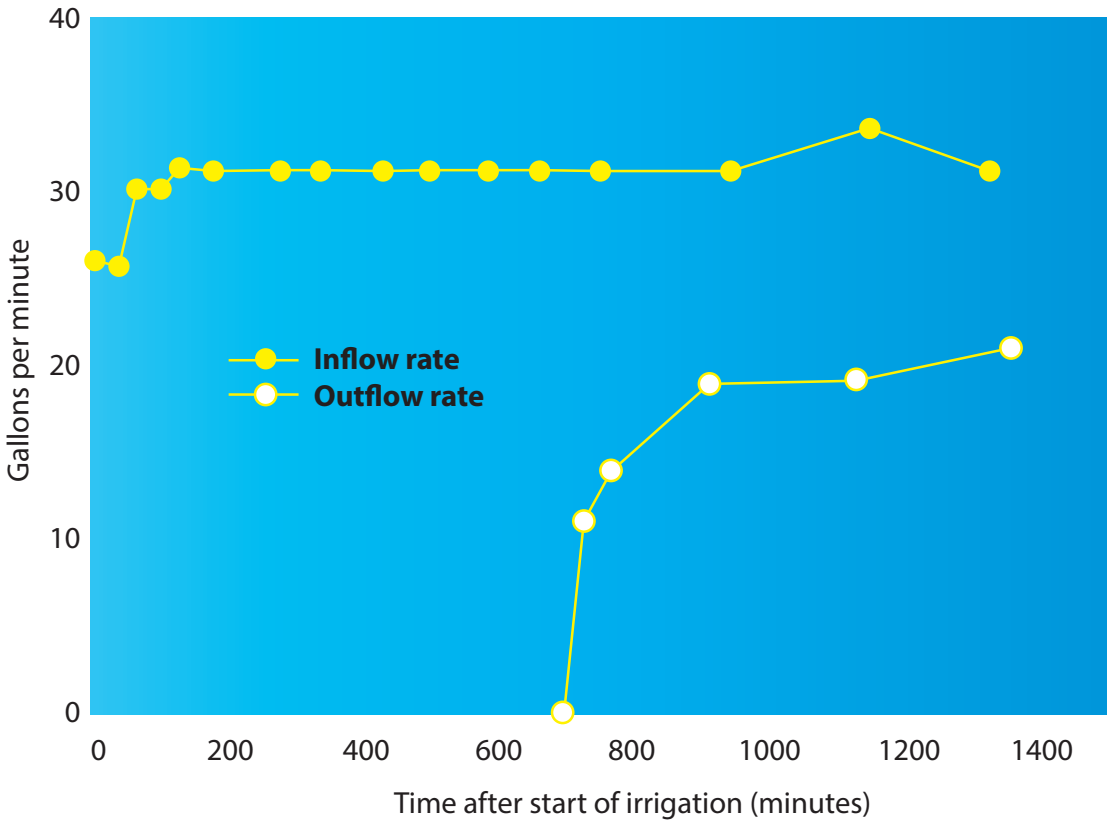

Figure 7. Furrow irrigation inflow and outflow rates (gpm) over the duration of irrigation. After Hanson and Schwankl 1995.

time at the tail end of the field. The result is significant: about twothirds of the inflow water runs off for 500 minutes. A shorter cutoff time would reduce runoff volume but may also slightly reduce the distribution uniformity across the field.

Blocking furrows by making small dams in the length of the furrow can increase infiltration and help uniformity. This practice of monitoring each furrow during irrigation is labor intensive but can reduce runoff volume.

Capturing and recycling runoff by using a tailwater return system can mitigate runoff and offsite movement of residue, and it can also make irrigation more efficient. For more information, see the section "Tailwater Runoff Collection and Recycling," 


\section{Pressurized irrigation systems}

Pressurized systems should be operated to meet the orchard's water requirement while eliminating surface runoff. Uniformity is usually designed into pressurized irrigation systems, with management left to ensure not only efficiency but also the elimination of runoff losses by turning the system off before runoff occurs. In orchards with some slope, a small amount of runoff tends to accumulate from each emitter or sprinkler, potentially causing offsite movement. Improving uniformity of water application can reduce runoff. Sprinkler nozzle wear can increase application rates to the point of exceeding the soil's infiltration rate at the end of the irrigation when infiltration rate declines. Clogged emitters decrease uniformity, leading to under-application is some areas and over-application in others. All nozzles should be the same size to minimize application pressure differentials. Unfortunately, many well-engineered irrigation systems are not managed to their full potential because they need constant monitoring and maintenance.

\section{Improving Water Infiltration to Reduce Runoff}

Poor water infiltration can increase runoff from irrigation or winter rains. Irrigation runoff is typically associated with surface irrigation, but it can occur with pressurized systems on soils with poor infiltration or sloping land.

The first step in determining how to mitigate poor water infiltration is to understand the soil and water factors that influence it. At the onset of irrigation, water infiltrates at a high rate. Initially, the soil is dry and may have cracks through which water can infiltrate rapidly. After the soil near the surface wets for a few hours, the clay particles swell, closing cracks and limiting access to soil pores, which decreases infiltration rates. As wetting continues, the salinity and salt composition of the soil-water (water contained between soil particles) begins to more closely reflect that of the irrigation water, which is generally less saline. This reduction in soil water salinity retards water infiltration.

Water infiltration can be improved by increasing the soil total pore volume or individual pore size and by providing better access to surface pores. Physical practices that disrupt the soil and applying chemical and organic amendments are attempts to influence these factors. For an in-depth analysis of water infiltration problems and solutions see Singer et al. 1992.

\section{Impact of Soil Structure on Water Infiltration}

\section{Pores}

Pores are the spaces between mineral and organic particles in soils through which water and air move. Soils with a predominance of sand (larger, spherical particles) tend to have larger pores, while soils with a predominance of clay (plate-like particles) tend to have smaller pores. With some exceptions, soils with larger pores generally have higher infiltration rates. Water usually moves more slowly through small-pored soils because the smaller pores provide more surface area for water to adhere to. On the other hand, clay soils that form cracks as the soil dries and shrinks can have higher water infiltration rates, at least initially.

Individual soil particles can clump together, forming larger structures called aggregates. The small pores between particles remain, and larger pores formed between the aggregates significantly enhance water infiltration and gas exchange (fig. 8). Soil water
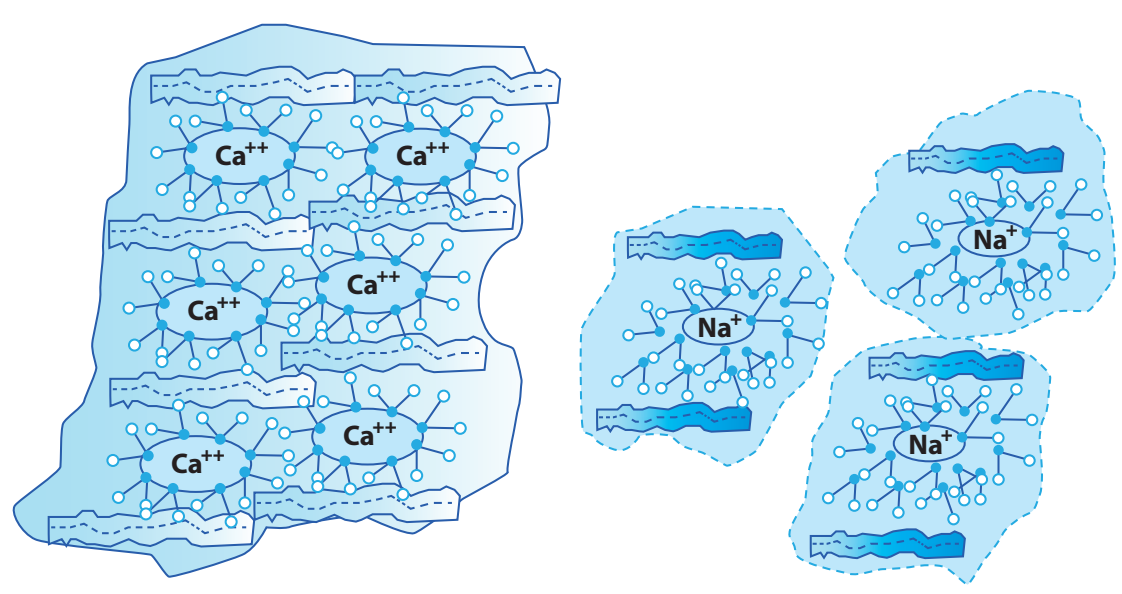

Figure 8. Soil aggregate stability: forming stable aggregates with plentiful calcium on clay exchange sites (left), compared with weak soil aggregates due to low salinity and/or excessive sodium in the soil pore water (left). 
salinity and individual mineral constituents, as well as organic matter content, play a significant role in stabilizing soil aggregates and increasing pore size.

\section{Soil crusts}

Soil crusts, or surface seals, reduce infiltration by impeding water access to soil pores beneath the crust layer. Crusts form at the soil surface when the soil aggregates become dispersed, causing a loss of porosity at the soil surface. Weak cementation of the crust often follows when the soil dries, slowing water penetration during succeeding irrigations. Soil surface crusts can be either structural crusts or depositional crusts, as defined below.

Structural crusts form when surface soil aggregates are destroyed by the impact of rain or sprinkler droplets. The mechanical breakdown of soil aggregates tends to segregate soil particles, leaving a film of finer particles on top (the sealing layer) that blocks the entry of water into the larger, intact pores beneath. Another type of structural crust forms under furrow irrigation through a process is called slaking. As the soil is wetted, a combination of mechanical and chemical dispersion of soil aggregates occurs, causing the structure to collapse. Upon drying the crust becomes hard.

Depositional crusts form when small (usually clay- and silt-sized) soil particles suspended and transported in flowing water settle out of suspension and form a thin, low-porosity surface layer. In agricultural settings, this type of soil crust is most caused by highvelocity water in the head end of the furrow or check eroding fine particles that settle out when the water slows.

Both structural and depositional crusts are thin and are characterized by higher density, greater strength, and smaller pores than the underlying soil. These crusts are usually less than 0.1 inch thick but often limit infiltration for the entire root zone (Figure 9). Structural crusts are a far more common cause of poor water infiltration problems in California orchards than depositional crusts.

In fine-textured silty soils, soil crusts are often the result of sodic conditions caused by excess exchangeable sodium in the soil

\section{Structural}

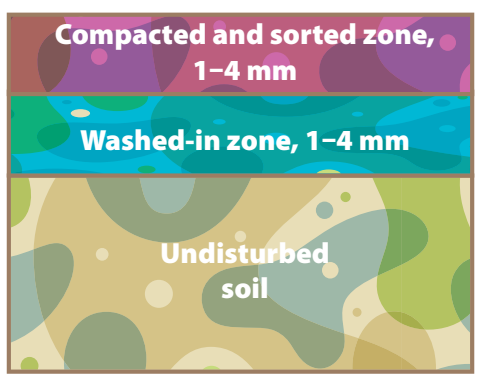

Figure 9. Structural versus depositional crusts.

or irrigation water and too little total salinity. In coarse- to mediumtextured nonsaline and nonsodic soils, continued cultivation can reduce pore size and number to the point where water infiltration is affected. This problem can be made worse where irrigation water with very low salinity is used, such as from irrigation districts on the east side of the San Joaquin Valley. Additionally, wells that contain high levels of bicarbonates and relatively low levels of calcium encourage crusting. The increased use of herbicides for no-till management can also decrease soil organic matter and soil microbial activity. This also results in decreased soil aggregation and reduced pore size.

\section{Impact of Irrigation Water Quality on Water Infiltration}

Irrigation water quality (salinity and sodicity) influences water infiltration rates by affecting whether soil particles tend to absorb water, stay together, or become separated by swelling. The swelling of soil particles causes aggregate breakdown and soil particle dispersion, resulting in the formation of surface crust.

\section{Salinity}

The higher the salinity of the irrigation water, the more likely that aggregates will remain stable, preserving infiltration rates. Salinity is measured by determining the electrical conductivity (EC) of the irrigation water $\left(\mathrm{EC}_{\mathrm{w}}\right)$ or soil water extracted from a saturated soil paste $\left(\mathrm{EC}_{\mathrm{e}}\right)$. 


\section{Sodicity}

The index for sodicity is the sodium adsorption ratio (SAR), which depends on the relative amounts of sodium, calcium, and magnesium in the irrigation water. The SAR of a soil sample can also be used to estimate exchangeable sodium levels in the soil. With increasing levels of exchangeable sodium, the affinity of soil particles for water increases and aggregate stability decreases, reducing water infiltration rates.

\section{Combined effect of salinity and sodicity}

Since both the salinity and sodicity of irrigation water affect aggregate stability and water infiltration, both must be assessed when diagnosing poor infiltration. In the top 3 inches of soil, the salinity and sodicity of the irrigation water and soil are closely linked. Consequently, samples of surface soil and irrigation water must be tested to diagnose the problem and evaluate the likelihood of success of mediation practices. In general, aggregate stability and infiltration rates increase as EC increases and the SAR decreases (table 8). As a general guideline, the SAR should be less than 5 times the EC (fig. 10). The exception is low-salt water with EC values of less than $0.5 \mathrm{dS} / \mathrm{m}$, which is corrosive and depletes surface soils of readily soluble minerals and all soluble salts. It often has a strong tendency to dissolve all sources of calcium rapidly from surface soils. The soils then break down, disperse, and seal, resulting in poor water infiltration.

Table 8. Potential for a water infiltration problem

\begin{tabular}{|l|l|l|}
\hline SAR & $\begin{array}{l}\text { Problem likely, ECet or ECw } \\
\text { (dS/m) }\end{array}$ & $\begin{array}{l}\text { Problem unlikely, ECe or ECw } \\
\text { (dS/m) }\end{array}$ \\
\hline $0-3.0$ & $<0.3$ & $>0.7$ \\
\hline $3.1-6.0$ & $<0.4$ & $>1.0$ \\
\hline $6.1-2.0$ & $<0.5$ & $>2.0$ \\
\hline
\end{tabular}

Source: Ayers and Westcot 1985.

Notes: *Sodium adsorption ratio.

†Electrical conductivity of a soil saturated paste.

sElectrical conductivity of irrigation water.

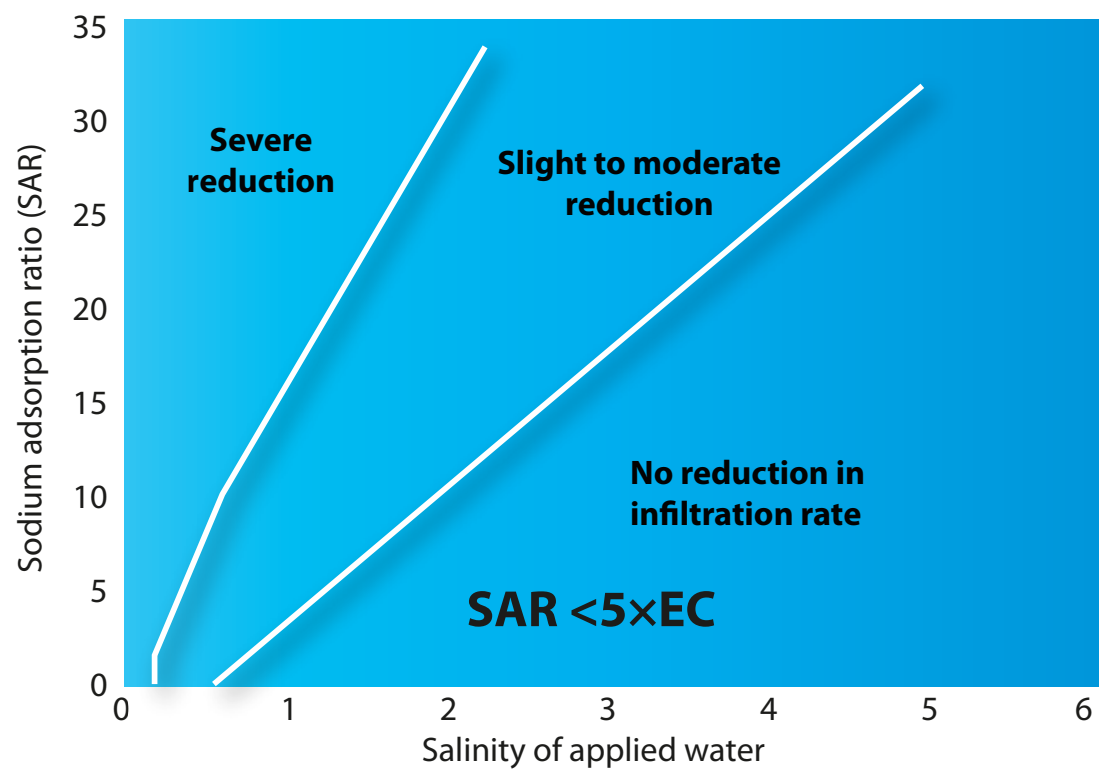

Figure 10. Interaction of total salinity as ECw with the sodium adsorption ratio (SAR) of irrigation water for causing potential infiltration problems.

The guidelines based on EC and SAR discussed above may not work for all California soils. Some soils contain a large amount of serpentine clays rich in magnesium $(\mathrm{Mg})$ and low in calcium $(\mathrm{Ca})$. In these soils, magnesium may have the same soil-dispersing effect as sodium. Soils with a predominance of montmorillonite and illite clays are also easily dispersed by excess magnesium. Although the diagnostic criteria for such conditions have not been extensively tested, some studies suggest that when the magnesium to calcium ratio of these soils exceeds 1:1, they may be prone to poor water infiltration. Some studies report that high levels of soil potassium can also promote aggregate dispersion and soil crusting.

High levels of carbonate $\left(\mathrm{CO}_{3}^{-}\right)$and bicarbonate $\left(\mathrm{HCO}_{3}^{-}\right)$in water increase the sodium hazard of the water to a level greater than that indicated by the SAR. In alkaline soils, high levels of carbonate and bicarbonate tend to precipitate calcium carbonate (lime, $\mathrm{CaCO}_{3}$ ) and magnesium carbonate $\left(\mathrm{MgCO}_{3}\right)$ when the soil solution becomes concentrated during soil drying. The concentrations of calcium and magnesium in the soil solution are reduced relative to sodium, and the SAR of the soil solution tends to increase.

An adjusted SAR value may be calculated for water high in carbonate and bicarbonate if the soil being irrigated contains free 
lime (calcareous soil). The adjusted SAR and knowledge of soil properties help determine management practices when using highbicarbonate water.

\section{Mitigating Poor Water Infiltration}

Solving poor infiltration by modifying irrigation practices, as discussed in other sections of this publication, should always be the starting point and will generally be less costly than the soil and water modifying treatments discussed below. Water infiltration problems not amenable to improvement by optimizing irrigation system design and operation may be mitigated by improved soil organic matter management or the use of chemical amendments discussed later in this publication.

\section{Tillage}

Shallow tillage can disrupt structural and depositional crusts. Where crusting reduces infiltration rates, a single tillage can restore infiltration rates. However, in soil with severely reduced infiltration, tillage before each irrigation is common. Shallow tillage using shallow disking or harrowing can break up the surface crust. Shallow tillage to incorporate the pesticide after application can effectively reduce the residues available for offsite movement. Some orchards have been planted in nonuniform layered soils without deep tillage prior to planting, and examination of backhoe pits in them can reveal significant hardpan and other layers that limit root development. Tillage of orchard middles is limited to a single pass, with the depth related to the draft force required and traction of the tractor.

Ripping will damage existing roots, especially in orchards where poor water infiltration has been limiting root zone depth. However, the improved soil characteristics and root pruning will help to encourage new root growth. Roots take time to begin growing, and regrowth varies with the season and the carbohydrate status of the tree. In any event, do not till all the middles at once; tilling alternate middles each year produces the best results. Ripping is most be most effective in the fall, after harvest when water use is low and soils are dry and easy to shatter and mix.

\section{Soil organic matter}

Soil organic matter helps stabilize soil aggregates by increasing the number of exchange sites in the soil matrix and encouraging microbial activity. Soil microbes that decompose soil organic matter produce polysaccharides and polyuronides, which act as binders to stabilize aggregates, improving porosity and water infiltration. Over time, continued cultivation and the use of herbicides reduce the organic matter content and aggregate stability of soils. These changes can reduce water infiltration and increase runoff potential.

In most of California, it is difficult to increase and sustain soil organic matter under the prevailing warm, semiarid conditions that favor rapid organic matter decomposition. Adding organic matter additions to improve or sustain aggregate stability and water infiltration must be incremental and continual to be effective. Growers can achieve this in the following ways.

\section{CROP RESIDUES}

Tree leaves and prunings, shredded or incorporated into the soil, can be left to decompose, adding organic matter and some nutrients to the soil.

\section{MANURE AND OTHER ORGANIC MATERIALS}

With proper handing and management to avoid risk of crop contamination by human pathogens, animal manure or compost can help increase soil organic matter content and improve water infiltration. However, the application of manure is currently uncommon due to their limited availability.

\section{COVER CROPS}

Cover crops can help protect the soil surface from droplet impact of winter rainfall or sprinkler irrigation and can provide significant organic matter biomass for decomposition and microbial stabilization of soil aggregates. In addition, cover crop residue can slow the velocity of surface water, reducing erosion and subsequent depositional crusting. Winter annual cover crops are most often planted in orchards because they grow during the wet season, reducing the competition for water and nutrients that is a disadvantage of perennial cover crops. Annuals are sown or allowed to reseed in the fall and mowed or disked 
in the spring. A winter annual cover crop planted in fall, grown during the winter and early spring, and mowed or disked to remove it in spring can produce as much as 3 tons of dry matter above and below ground per planted acre. A comprehensive review of this topic is available in Grant et al. 2006.

\section{Chemical Amendments}

Adding chemical amendments to water or soil can improve water infiltration by increasing the total salt concentration or decreasing the sodium adsorption ratio (SAR) of the soil-water. These actions enhance aggregate stability and reduce soil crusting and pore blockage. Four types of materials are used to ameliorate water infiltration: salts, as fertilizers; calcium materials; acids or acidforming materials; and soil conditioners, including polymers and surfactants.

\section{Salts}

Any fertilizer salt or amendment that contains salts, when applied to the soil surface or dissolved in irrigation water, increases the salinity of the irrigation water and ultimately influences the soilwater. Whether increased salinity is advantageous depends on the SAR of the irrigation water. The largest effect of salt addition is with irrigation water that has very low salinity (EC less than 0.5). Increasing salinity to an EC of above $4 \mathrm{dS} / \mathrm{m}$ has little effect on infiltration.

\section{CALCIUM MATERIALS}

Adding calcium salts to soil and water increases the total salinity and soluble calcium. The calcium salt commonly used on alkaline (high-pH) soils is gypsum $\left(\mathrm{CaSO}_{4}\right)$, but calcium chloride $\left(\mathrm{CaCl}_{2}\right)$ and calcium nitrate $\left(\mathrm{CaNO}_{3}\right)$ are sometimes used. These are fairly soluble and can easily be applied though the irrigation water. Care should be taken if the water contains more than $2 \mathrm{meq} / \mathrm{L}$ of bicarbonate $\left(\mathrm{HCO}_{3}\right)$. Adding gypsum to such water through a drip system significantly increases the likelihood that lime precipitate will clog the system; if it does, application of acid to decrease bicarbonate concentrations may be necessary. Lime and dolomite are used only for broadcast applications on acid soil, as they are virtually insoluble under alkaline conditions.

\section{GYPSUM INJECTION RATES FOR WATER}

Adding gypsum to irrigation water at rates that supply 1.0 to 3.0 $\mathrm{meq} / \mathrm{L}$ of calcium is considered low to moderate; rates that supply 3.0 to $6.0 \mathrm{meq} / \mathrm{L}$ of calcium are considered moderate to high. The following sample calculations show how to estimate the quantity of gypsum required to improve infiltration. Table 9 gives the amount of gypsum and other products needed to increase the calcium content of irrigation water by $1 \mathrm{meq} / \mathrm{L}$ per acre-foot; applying 234 pounds of $100 \%$ pure gypsum per acre-foot of water provides $1 \mathrm{meq} / \mathrm{L}$ of free calcium. It is rarely necessary to inject gypsum constantly. Injection every other or every third irrigation may be all that is necessary to end the season with the required amount more beneficial than applying it to the surface during the fallow season.

Table 9. Amounts of amendments required for calcareous soils to increase the calcium content in the irrigation water by $1 \mathrm{meq} / \mathrm{L}$

\begin{tabular}{|l|l|c|}
\hline Chemical name & $\begin{array}{l}\text { Trade name and } \\
\text { composition }\end{array}$ & $\begin{array}{c}\text { Amount per acre-foot of } \\
\text { water to obtain } \mathbf{1} \text { meq/L } \\
\text { free calcium* }\end{array}$ \\
\hline sulfur & $100 \% \mathrm{~S}$ & 43.6 \\
\hline gypsum & $\mathrm{CaSO}_{4} \cdot 2 \mathrm{H}_{2} \mathrm{O}, 100 \%$ & 234 \\
\hline calcium polysulfide & Lime-sulfur, 23.3\% S & 191 \\
\hline calcium chloride & Electro-Cal, 13\% calcium & 418 \\
\hline potassium thiosulfate & $\mathrm{KTS}, 25 \% \mathrm{~K}_{2} \mathrm{O}, 26 \% \mathrm{~S}$ & 256 \\
\hline ammonium thiosulfate & Thio-sul, 12\% N, 26\% S & $110^{\dagger}$ \\
\hline ammonium polysulfide & Nitro-sul, 20\% N, 40\% S & $336^{\S}$ \\
\hline $\begin{array}{l}\text { monocarbamide dihydrogen } \\
\text { sulfate/sulfuric acid }\end{array}$ & $\begin{array}{l}\mathrm{N}-\text {-phuric US-10, 10\% N, } \\
18 \% \mathrm{~S}\end{array}$ & $69^{\dagger}$ \\
\hline sulfuric acid & $100 \% 6^{\S} \mathrm{HO}_{4}$ & $148^{\dagger}$ \\
\hline Notes: & & $242^{\S}$ \\
\hline
\end{tabular}

Notes:

*Salts bound to the soil are replaced on an equal ionic charge basis and not on an equal weight basis.

${ }^{+}$Combined acidification potential from $\mathrm{S}$ and oxidation of $\mathrm{N}$ source to $\mathrm{NO}_{3}$ to release free $\mathrm{Ca}$ from soil lime. Requires moist, biologically active soil.

${ }^{\S}$ Acidification potential from oxidation of $\mathrm{N}$ source to $\mathrm{NO}_{3}$ only. 


\section{GYPSUM RATES BROADCAST TO SOIL}

An alternative to treating water with calcium materials is broadcasting amendments such as gypsum on the soil surface and irrigating the amendment into the soil. The primary advantage of this approach is that it is often less expensive than water treatments. However, for surface application to be nearly as effective as water treatment, it must be properly timed. If infiltration is a problem in the summer months, apply the amendment at the onset of those months, not in the preceding fall or winter. If the application is made too early, the amendment will percolate with postharvest irrigations and winter rainfall to depths below where the crust forms. Surface applications are most effective when gypsum is applied at rates equivalent to 500 to 1,000 pounds of gypsum per acre prior to the onset of irrigation. Use finely and consistently ground gypsum products in surface applications. Applications that are limited to the berm have been successful at decreased field rates (the same rate per unit area but applied to the berm only) when using drip irrigation. For maximum effect on surface crusting, do not till the soil after the gypsum is applied.

\section{Acids and acid-forming materials}

Commonly applied acid or acid-forming amendments include sulfuric acid $\left(\mathrm{H}_{2} \mathrm{SO}_{4}\right)$ products, soil sulfur, ammonium polysulfide, and calcium polysulfide. The acid from these materials dissolves soil-lime to form a calcium salt (gypsum), which dissolves in the irrigation water to provide exchangeable calcium. The acid materials react with soil-lime the instant they come in contact with the soil. Materials containing elemental sulfur or sulfides must undergo microbial degradation in order to produce acid. This process may take months or years, depending on the material and particle size (in the case of elemental sulfur). Since these materials form an acid via the soil reaction, they reduce soil $\mathrm{pH}$ if applied at sufficiently high rates.

Acids are applied to water for two purposes in relation to water infiltration problems. The first is to dissolve soil lime (the soil must contain lime if acids are used), which increases free calcium in the soil-water and improves infiltration. The second is to prevent lime clogging in drip systems when adding gypsum to water containing greater than $2 \mathrm{meq} / \mathrm{L}$ bicarbonate.
Table 9 indicates that it takes 133 pounds of $100 \%$ pure sulfuric acid per acre-foot of water to release $1 \mathrm{meq} / \mathrm{L}$ of calcium. This assumes that the acid contacts lime in the soil, neutralizing the carbonate molecule and releasing calcium. This is the same amount of acid required to neutralize $1 \mathrm{meq} / \mathrm{L}$ of bicarbonate in the water. If the water contains bicarbonate, the acid will neutralize it, converting it to carbon dioxide, which is released to the atmosphere. To dissolve lime in the soil, the level of acid applied must be greater than the level of bicarbonate in the water; if the level of acid is lower, the $\mathrm{pH}$ of the water will not decrease.

\section{Soil conditioners}

The primary soil conditioning amendments are surfactants and organic polymers. Although there is a long history of developing and testing other amendments, such as synthetic and natural soil enzymes and microbial soups, not enough data exists on them to conclude that they are uniformly effective. Surfactants, or wetting agents, reduce the surface tension of water; they are not effective in agricultural soils.

\section{ORGANIC POLYMERS}

Organic polymers, mainly water-soluble polyacrylamides (PAM) and polysaccharides, stabilize aggregates at the soil surface. These extremely long-chain molecules wrap around and through soil particles to bind aggregates together. This action helps resist the disruptive forces of droplet impact and also helps decrease soil erosion and sediment load in furrow irrigation systems. Studies have shown that PAM can improve infiltration into soils with illite and kaolinitic clays common in the northwest United States (Sojka et al. 2007). Research conducted in California found that infiltration is not improved in soils with the mostly montmorillonite (swelling) clays typical of the San Joaquin Valley (Long et al. 2010a). For more information on water infiltration, see Singer et al. 1972 .

Water-soluble PAM is not to be confused with the crystallike, cross-linked PAMs that expand when exposed to water and do not influence water infiltration. Cross-linked PAMs enhance the 
water-holding capacity of soils for small-scale applications, such as in container nurseries.

The effect of organic polymers on infiltration depends on polymer properties, such as molecular weight, structure, and electrical charge, and the salinity of the irrigation water. Charged (ionic) and noncharged (nonionic) polymers can behave differently depending on whether they are added to very pure water (surface water where EC is 0.03 to $0.1 \mathrm{dS} / \mathrm{m}$ ) or higher-salinity well water (above $0.8 \mathrm{dS} / \mathrm{m}$ ).

Polymers have been shown to work best when sprayed on the soil surface at a rate of about 4 pounds per acre, followed by an application of gypsum in soil or water.

\section{SURFACTANTS}

Surfactants, or wetting agents, are amendments that reduce the surface tension of water and improve infiltration in hydrophobic soils, which include forest and other soils with high organic matter content. They are not generally effective in agricultural soils.

\section{Other amendments}

Other amendments include synthetic and natural soil enzymes and microbial soups. Although there is a long history of soil conditioner development and testing, not enough data exists on the materials to conclude that they are uniformly effective.

\section{Capturing and Filtering Surface Water and Sediments}

Reducing the volume or velocity of runoff water can reduce offsite movement of residues, whether in solution or attached to sediment. Some methods of capturing and filtering surface water and sediment are temporary and are used with a new orchard or in emergency situations where the need for runoff control is short lived. Hillside orchards should have several types of permanent erosion control measures in place, such as permanent cover crops, adequately sized filter strips between the orchard and waterways, and permanent sediment basins for collection and or recycling or vegetation at the tail of the field or in the drainage ditch.

\section{Storing Storm Runoff}

Storage of runoff water from storm events in impoundments is often suggested as mitigation for the offsite movement of pesticides. However, the volume of runoff makes this a poor option. Storms are rated as to the frequency at which a particular amount of rainfall in a given duration is expected to return. A 2-year 24-hour storm would be the rainfall event one could expect during a 24-hour period on the average of every 2 years. For example, a 2-year, 24-hour storm in Stockton, California, is 1.6 inches. That amount of rainfall on a 40 -acre parcel would produce over $1,700,000$ gallons, or 5.3 acre feet, of water, equivalent to a 1 -acre pond over 5 feet deep. A single hundred-year storm would require three times that volume. Of course, some of the water would infiltrate into the field. However, if one storm came on the heels of another, most of the rainfall would run off. For more information, see Schwankl et al. 2007a.

\section{Temporary measures}

\section{FILTER FABRIC FENCING}

A barrier of filter cloth with woven wire stretched between temporary fence posts across a slope can reduce soil movement. Make sure the posts are on the down-slope side of the fencing.

\section{STRAW BALE CHECK DAM}

To construct a check dam, place bales of clean straw bound with wire or plastic twine across an area of surface sheet flow or gully erosion and anchor them into the soil surface with rebar or stakes.

\section{STRAW BALE WATER BARS}

Place straw bales across a road to create a temporary water bar or on slopes to act as a temporary sediment barrier. A series of straw bale water bars may be needed for long slopes. 


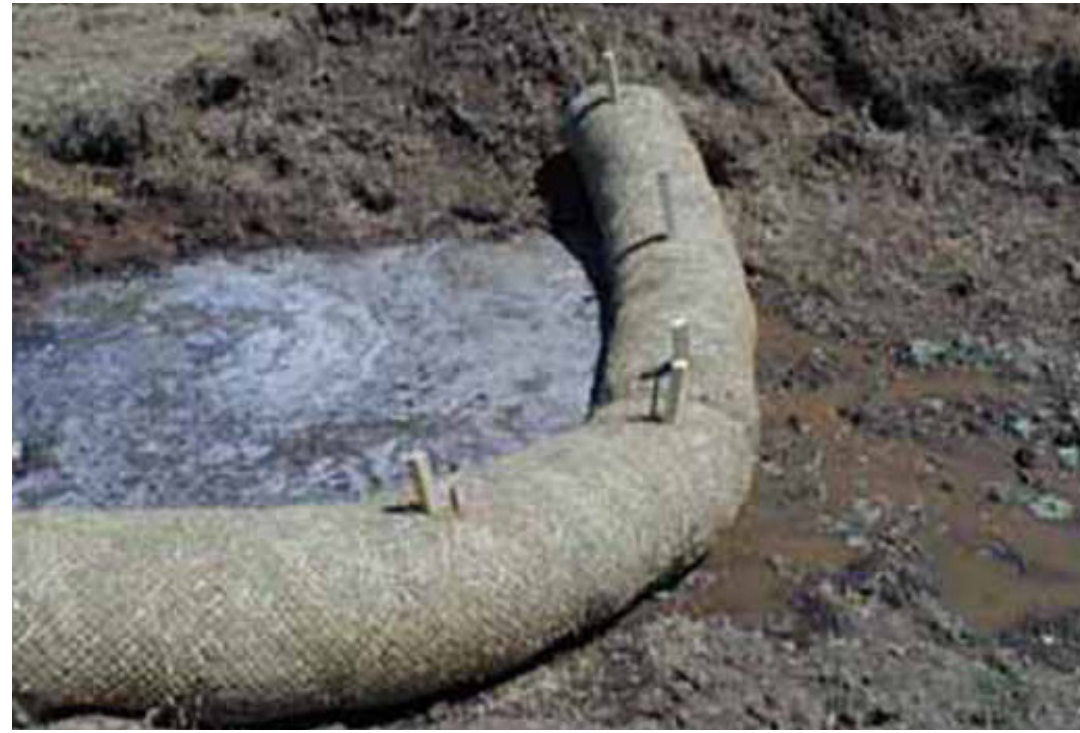

Figure 11. Straw wattles for erosion control. Photo: L. Schwankl

\section{STRAW WATTLES}

Straw wattles or fiber rolls are designed to slow runoff, reducing erosion and filtering and trapping sediment before the runoff gets into water courses. Straw wattles must be installed on the contour (fig. 11).

\section{TEMPORARY DRAINAGE STRUCTURE}

Constructed at the tail of a field, temporary drainage structures slow and trap runoff for short periods of time (fig. 12). The water eventually infiltrates the soil.

\section{TEMPORARY SEDIMENT BASIN}

Temporary sediment basins catch and settle out sediment before it can enter a waterway. They are usually placed at the base of a slope or drainage area. A small basin can be created from compacted soil and rocks or straw bales. The embankment should not exceed 4 feet in height, and a drain or outlet should restrict flow from the basin to allow sediment to be trapped.
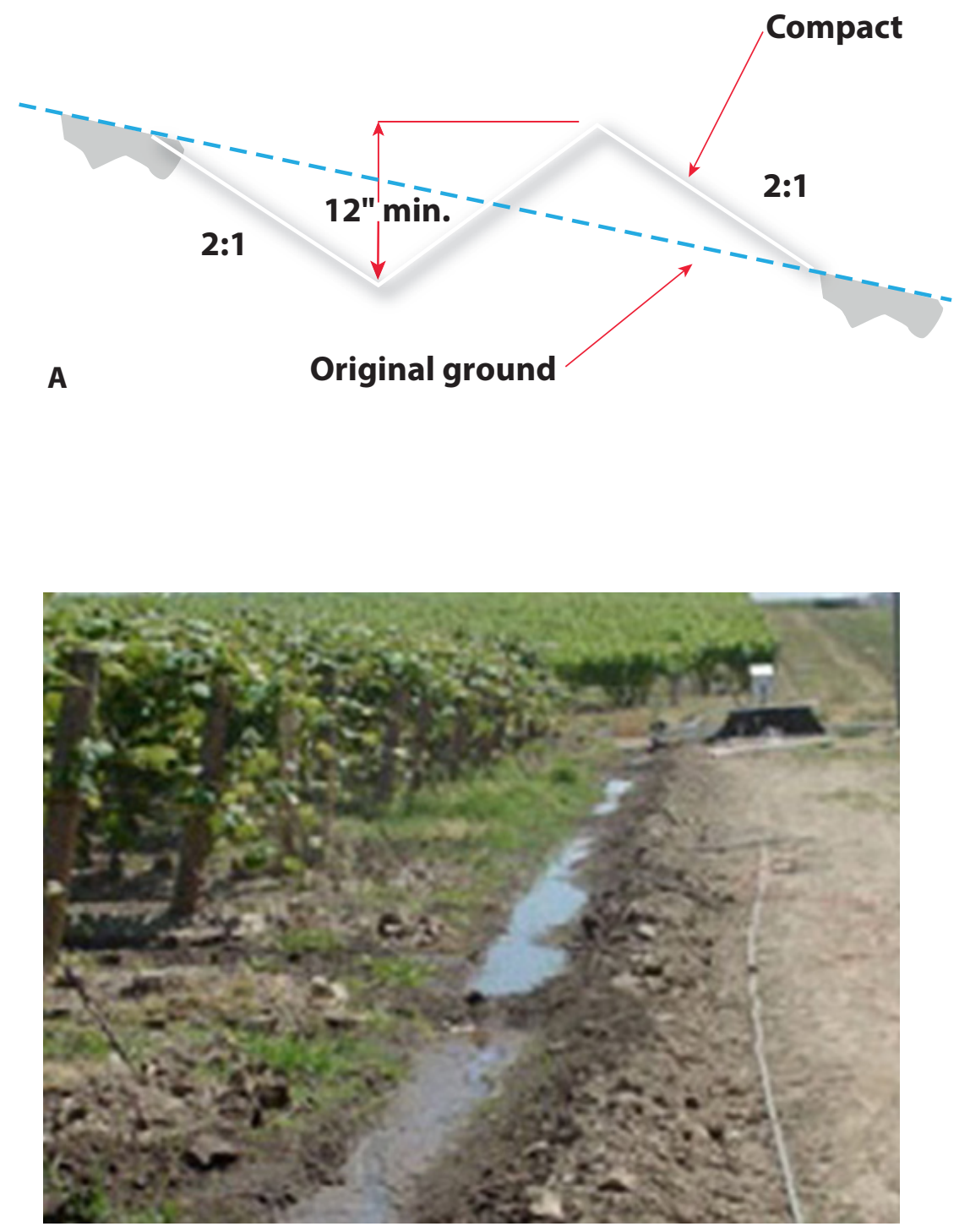

Figure 12. Temporary drainage structure schematic (A) and construction (B). Photo: L. Schwankl 


\section{Permanent measures}

\section{SEDIMENT BASINS}

A sediment basin or trap consists of an embankment, a basin emergency spillway, and a perforated pipe-riser release structure (fig. 13). The basin may be located at the bottom of a slope where drainage enters a swale or waterway. These basins can be designed by the Natural Resources Conservation Service (NRCS) or a civil engineer on a site-specific basis and installed using proper construction and compaction for the berm and correct sizing and construction for water release structures and spillways. When runoff volumes are small, basins can effectively reduce offsite movement of sediment containing adsorbed pesticide residues. The efficiency of sediment removal declines rapidly when a high volume of runoff causes water to run through the basin too quickly.

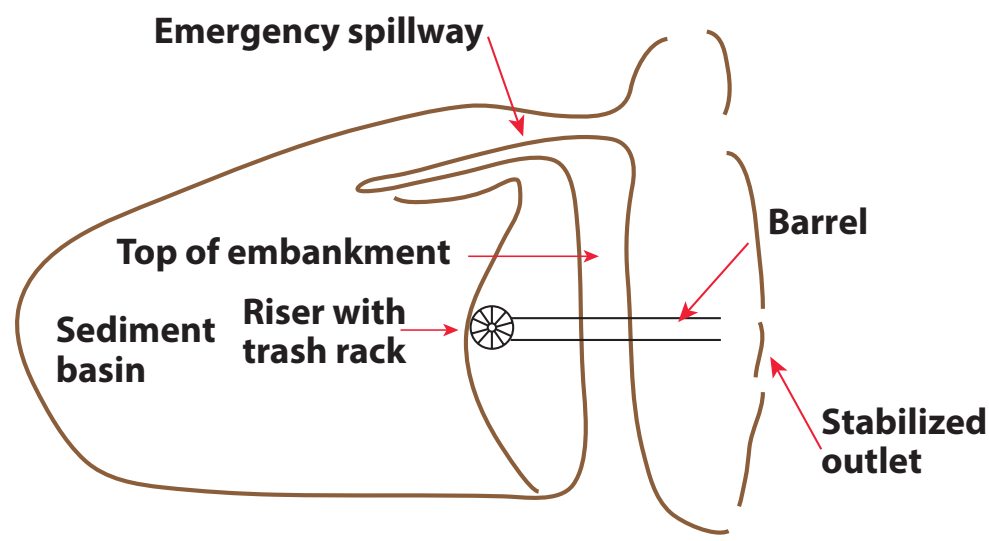

Figure 13. Sediment basin with spillway and release structure.

\section{EFFECTIVENESS IN REMOVING PESTICIDE RESIDUES}

Long et al. (2010b) found that retention times of 60 to 90 minutes in a sediment basin that was $1.4 \%$ of the irrigated area effectively removed particles coarser than fine silts. Finer soil particles, which generally adsorb pyrethroid pesticide residues, were not removed from the runoff. During the first irrigation of the season (soon after cultivation in a furrow-irrigated crop), 39\% of the sediment load entering the pond was removed. In the second measured irrigation, sediment removal was insignificant. The effectiveness of sediment traps was found to be limited by the time available for suspended sediments to settle out of the runoff before discharge. Sediment basins may be ineffective with finer soils at higher runoff rates. Long (2010b) suggests settling basins of various size based on Stokes' Law. Clay particles carry the bulk of the adsorbed pesticide residues. A settling basin of 57 acre feet would be required to provide enough time to settle these small particles out of tailwater runoff at 50 gallons per minute.

A study was conducted in the Central Valley to measure pyrethroid removal by a tailwater recovery pond (Markle 2009). A pyrethroid, lambda-cyhalothrin, was applied to a border-checkirrigated almond orchard at the rate of 0.04 pounds of active ingredient per acre. Runoff water was measured for volume, sediment, and pyrethroid residue concentration as inflow and outflow in a recycling pond that was 19 feet by 16 feet by 7 feet deep. About $15 \%$ of the irrigation onflow water exited the field as runoff. The pond reduced the sediment in the water by $80 \%$ and pyrethroid residues by $61 \%$ (inflow to outflow). The difference in the removal efficiencies for sediment and pyrethroid residues was probably due to the adsorption of lambda-cyhalothrin residues to lighter-weight clay particles that did not have a chance to settle out in this trial. Removal efficiency may have been further improved with lower flow rates or longer retention times in the pond.

\section{Cover crops}

Cover crops are usually grown in orchard middles, with the rows kept free of vegetation. Plant species used for cover crops may be annuals (planted, grown, and removed each season) or perennials, 
which generally live 3 or more years. Annual cover crops can be composed of species that reseed themselves naturally each year (for example, annual clovers and medics), or they can be removed before they form seed and replanted each year. Perennials such as ryegrass, orchard grass, and fescues are not often used because they compete with the trees for water and nutrients during the summer.

Cover crops can help reduce offsite movement of waterborne pesticide residues in several ways. By shielding the soil from the impact of rain droplets, a winter-grown cover crop can help reduce the likelihood that soil particles will be eroded from the soil surface. Cover crop vegetation may also help slow sedimentation by directly filtering soil particles out of moving water and by slowing the speed of water moving over the soil surface. As the weather warms in late winter and spring, cover crops can help deplete excessive soil moisture and increase water storage potential (thus reducing runoff) from storm events at this time of year. For more information, see Grant et al. 2006 and O'Geen et al. 2006a and 2006b.

\section{EFFECTIVENESS IN REMOVING PESTICIDE RESIDUES}

Early-fall establishment of cover crops is critical to their effectiveness in capturing runoff water and sediments containing pesticide residues. Among the best cover crops are perennial sods that have dense foliage and root systems. Reseeding winter annual grasses such as Blando brome or Zorro fescue works well after establishment (see Ingels et al. 1998). Cover crops are often mentioned as being related to reducing the runoff of pesticide residues; however, research measuring such reduction is limited or nonexistent. However, numerous works measuring reduced runoff volumes and sediments when using cover crops have been published. In a Central Coast vineyard, Trios 102 triticale and Merced rye cover crops planted in vineyard middles reduced runoff volumes from 46 to $78 \%$, respectively, when compared with bare soil (Smith et al. 2008). These comparisons, made over a 3-year period, also found a significant reduction in suspended sediment and turbidity.

\section{Vegetative filter strips}

A vegetative filter strip is any area of dense grass or other vegetation, natural or planted, between the orchard and a nearby waterway. Filter strips help capture and filter surface runoff from cropland to protect water quality. Tall, sturdy, hardy perennial grasses are preferred, since once established they withstand the force of runoff water and summer drought. The width of the strip required to effectively remove sediments depends on the slope of the area draining into the strip. For slopes of less than $1 \%$, the strip should be at least 25 feet wide, increasing proportionally with the increase in slope up to 50 feet wide for $10 \%$ slopes. Filter strips can also be used to reduce sediment flow between orchard blocks.

Vegetative filter strips function in three distinct layerssurface vegetation, root zone, and subsurface horizon (Grismer et al. 2006). As surface flow enters the strip, water is infiltrated until the shallow surface and shallow subsurface is saturated. During this infiltration, pesticide residues are trapped by soil constituents and organic matter, allowing pesticide degradation to occur. The flow volume and velocity is decreased, reducing sediment transport. Sediment particles are trapped on the surface litter layer, which is high in organic matter. As the process continues, water continues to move through the subsurface horizon, further decreasing the volume of runoff.

\section{EFFECTIVENESS IN REMOVING PESTICIDE RESIDUES}

The chemical characteristics of pesticides determine the type and amount of residue reduction achievable with vegetation systems. Organophosphate pesticides tend to be water soluble, while pyrethroids are virtually insoluble in water and are primarily adsorbed to sediments. Diazinon, an organophosphate highly soluble in water, can be expected to remain in solution for long periods (Bondarenko and Gan 2004). Previous evaluations of the effectiveness of vegetation for removing diazinon from water have shown mixed results. Watanabe and Grismer (2001) evaluated diazinon removal by vegetated filter strips under controlled laboratory conditions and found that the majority of diazinon removal occurred via infiltration into the root zone and adsorption 
to vegetated matter. However, $73 \%$ of the applied diazinon was detected in the runoff water from the VFS. Long et al. (2010b) found that reduction in sediment load was directly related to pyrethroid residue removal in a vegetated filter strip. Sediment runoff was reduced by $62 \%$ when furrow runoff water passed through a well-established strip planted to either tall fescue or to a mix of perennial ryegrass and tall fescue that represented $2.8 \%$ of the field being irrigated. They recommend 0.03 acres of vegetated filter per 100 gallons per minute of tailwater to significantly improve the water quality of field runoff (Long et al. 2010b). It should be noted that a vegetated filter strip is used once per irrigation, not for successive irrigation sets.

\section{Vegetated drainage ditches}

Drainage ditches can be vegetated with plant material that helps capture sediments and sediment-absorbed pollutants and also provides for some water infiltration (fig. 14). The common type of a vegetative drain ditch is a $\mathrm{V}$-shaped ditch 2 to 3 feet deep and 4 feet wide at the top. Short, sturdy, hardy perennial grasses such as dwarf fescues and perennial ryegrass are preferred, since once established they withstand the force of runoff water and summer drought. Vegetation in the ditch can also be resident, such as rushes and bermudagrass. Residue removal efficiency is strongly influenced by runoff flow rate per unit of ditch wetted area. Higher flow rates reduce the removal efficiency.

\section{EFFECTIVENESS IN REMOVING PESTICIDE RESIDUES}

Anderson et al. (2008) found that a vegetated ditch containing aquatic vegetation removed only $4 \%$ of diazinon in contaminated runoff. Moore et al. (2008) used a simulated runoff event to evaluate removal of diazinon in vegetated ditches in Yolo County, California. They described reductions in diazinon runoff using a V-shaped vegetated ditch, but significant concentrations of diazinon remained in the system outflow after five hours. Essentially, runoff water containing residues which are not infiltrated were little reduced.

Chlorpyrifos, another organophosphate, is more hydrophobic than diazinon. Gill et al. (2008) applied chlorpyrifos at 1 pint per acre and found a $40 \%$ reduction in the water column concentration after passage through a vegetated ditch, though the outflow water was still at 33 times the water quality standard of 15 parts per trillion. Anderson et al. (2008) found an average 35\% reduction of chlorpyrifos concentration in two evaluations after passage through a vegetative ditch containing aquatic vegetation. On the other end of the spectrum, Cole et al. (1997) found vegetated strips to be effective in reducing 62 to $99 \%$ of chlorpyrifos residues in runoff water. Local conditions, including runoff flow rates, size of the vegetated area, and the initial residue concentration, appear to have strongly influenced the effectiveness of these studies.

Because of their hydrophobic nature, pyrethroids adsorb readily to plant surfaces and soil particles and are therefore easier to remove from runoff water than are organophosphates (Moore et al. 2001; Schulz 2004). Moore et al. (2008), for example, found that vegetation was much

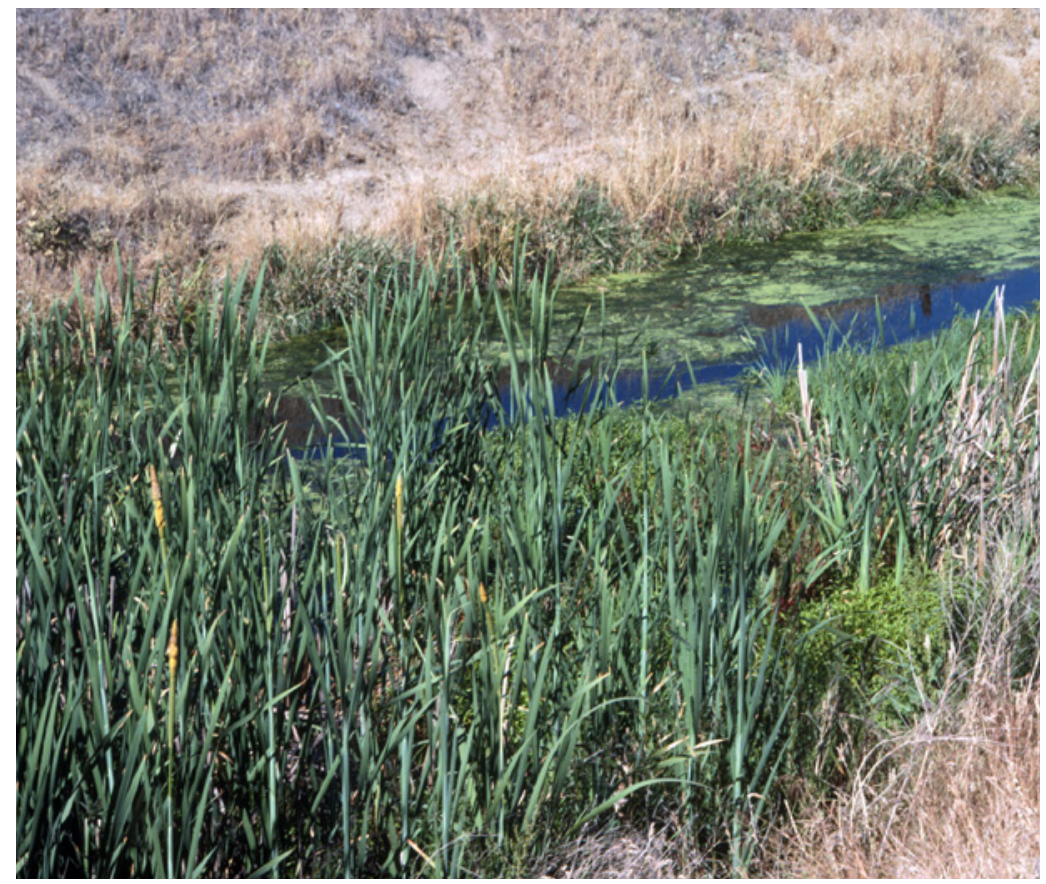

Figure 14. Vegetated drainage ditch. Photo: courtesy UC ANR. 
more effective at removing the pyrethroid pesticide permethrin than the organophosphate diazinon. Anderson et al. (2008) found nearly $100 \%$ reduction of permethrin after treatment in a vegetated ditch. Additionally, Gill et al. (2008) found a 25\% reduction of pyrethroid (lambda-cyhalothrin) residues after moving runoff water through a vegetated ditch.

\section{Tailwater Collection and Recycling}

Water running off the tail end of a field, part of normal irrigation, is referred to as tailwater or runoff water. Tailwater is most often associated with surface irrigation (furrow and border-check irrigation), since well-designed sprinkler and drip irrigation systems should not produce tailwater runoff. Using these systems is an excellent management practice to improve irrigation efficiency and minimize tailwater runoff impacts.

Tailwater collection systems (fig. 15) have most frequently been used in row and field crops and are not as common in surface-irrigated tree and vine crops. There is no reason tailwater

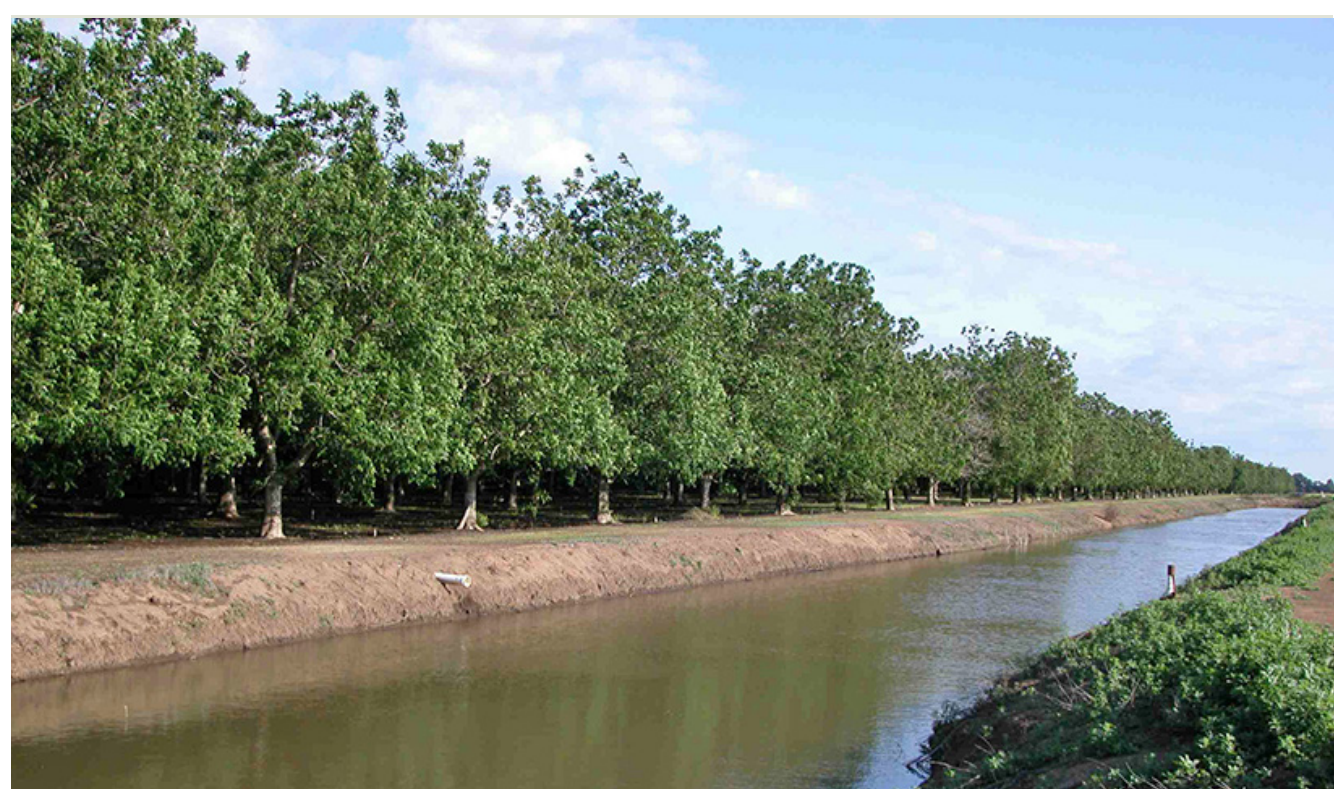

Figure 15. Tailwater collection system. Photo: L. Schwankl collection and recycling systems cannot be used in permanent crops using furrow or border-check irrigation. Their use is an excellent management practice to improve irrigation efficiency and minimize tailwater runoff impacts.

If a new tailwater return system is being planned, management is a key factor in its design. Tailwater generated by irrigation practices is most often pumped from the capture pond and conveyed via a pipeline system to where it will be reapplied. When operated properly, such a system maximizes irrigation efficiency and minimizes environmental impacts.

\section{Advantages of tailwater return}

- Offsite environmental impacts of tailwater potentially containing pesticide and fertilizer residues or sediment are minimized.

- Irrigation efficiency is improved since tailwater is beneficially reused as irrigation water.

- Water costs may be reduced by reusing tailwater.

- Tailwater collection systems remove standing water that can cause crop loss and weed infestations from the tail end of the field.

\section{Disadvantages of tailwater return}

- Cost of installation, maintenance, and operation of the tailwater return system. However, in many areas NRCS cost-share programs available.

- Land must be taken out of production for the pond and other tailwater recovery system components.

- Good management, requiring timely recycling of tailwater pond contents, is necessary to prevent groundwater pollution by chemicals in the tailwater.

\section{Tailwater return system management}

Tailwater return systems may be managed in several ways, which are often constrained by the system design. For more information, see Schwankl et al. 2007band NRCS 2006. 


\section{Treatment of Runoff Water}

Runoff water can be chemically treated to reduce pesticide residues. This treatment can be done in the furrow or check, in a tailwater ditch, or in a holding basin. Two products are available and have been shown effective for this purpose: Polyacrylamide (PAM) for treatment of pyrethroid-laden sediments, and Landguard OP-A Enzyme for treatment of most soluble organophosphate pesticides. Work is underway to develop enzymes to treat pyrethroid residues, but they are unavailable at this time.

\section{Polyacrylamide (PAM)}

PAM is effective in reducing sediment-adsorbed pesticide residues (generally, pyrethroids) that leave the field or are picked up in the tailwater ditch through erosion during irrigation. Studies have shown that this erosion occurs along the field length for furrow irrigation. PAM is a solid or liquid water-soluble polymer that flocculates sediments, binding them together and causing them to drop out of the water. When added to runoff water, PAM can mitigate transport of sediment-adsorbed pesticides from fields irrigated by furrow and border-check systems.

Liquid PAM can be constantly injected into the irrigation water, constantly deposited in granular form into turbulent irrigation ditch water, or applied to the furrow as dry tablets (40\% PAM) or granules (89\% PAM), where it is slowly dissolved by irrigation water. The in-furrow methods are generally less expensive and easier to apply than applying liquid or granular PAM to the inflow ditch or piped water. However, they do not allow for equally precise control of product concentration. Table 10 shows a comparison of costs using the different forms of PAM for an 80 -acre furrow-irrigated row crop planted on 5-foot beds, using data provided by a grower. The lowest cost occurred for granules placed in the furrow, while the costs were the highest using liquid PAM.

At a furrow length of 600 feet, 60 -inch beds would require about 1 ounce, or 2 tablets, per furrow. It is applied in a "patch" in a 3-foot section of the furrow, far enough from the furrow head to prevent sediments from covering the PAM patch. In the Northwest, placement 5 feet from the furrow head was successful. In California, the patch was quickly covered and not effective; whereas placement 100 feet down the furrow was successful. Once applied as a "patch," PAM seems to be effective for a few irrigations. If the soil is disturbed by cultivation, it must be reapplied. PAM is more effective in finer texture soils and in irrigation water that contains calcium and little sodium.

Season-long control costs are difficult to estimate because effectiveness from a single application varies with the number of irrigations and the number of field cultivations. Liquid PAM that contains oil-based carrier materials is available, but the cost per

Table 10. Cost comparisons for selected single-irrigation PAM dry formulations for a typical 80-acre furrow-irrigated row crop planted on 5 -foot beds

\begin{tabular}{|l|c|l|}
\hline Application method & Cost per ccre & Comments \\
\hline Granules placed in furrow & $\$ 1.24$ & 1 oz of granules per furrow \\
\hline Tablets placed in furrow & $\$ 6.38$ & 2 tablets per furrow $(50 \mathrm{~g}$ tablet) \\
\hline Granules injected into irrigation water & $\$ 3.36$ & $\begin{array}{l}\text { Target concentration }=5 \mathrm{ppm} \text {; injection time }=12 \mathrm{hr} \text { (time needed } \\
\text { for water advance to end of furrows) }\end{array}$ \\
\hline
\end{tabular}

Source: Long et al. 2010a with 2011 costs.

Note: Costs per acre are based on the irrigated acreage of the 80 -acre field. 
acre is high and the product can be toxic to some aquatic life at recommended field application rates (Weston et al. 2009).

\section{Effectiveness in removing pesticide residues}

PAM has been shown to be effective in reducing sediments from furrow-irrigated fields when applied to irrigation furrows. Sojka et al. (2007), in their Northwest studies on furrow-irrigated soils over a 3-year period, found application rates of 1 pound per acre of irrigation (about $10 \mathrm{ppm}$ ) eliminated $94 \%$ of sediment loss in field runoff. A seasonal rate of 3 to 7 pounds per acre was used, depending on the crop and number of cultivations. One of the mechanisms of decreased sediment loss is increased infiltration of irrigation water into the field, because PAM effectively reduces runoff water volume (Trout et al. 1995). Sojka, using the recommended 10-ppm PAM rate, found increases in infiltration of 15 to $50 \%$ compared with untreated controls. In California, Long et al. (2010b) found no PAM effect on infiltration into loam and clay loam soils at a lesser application rate assumed to be near $2 \mathrm{ppm}$.

In a California study conducted on loam and clay loam soils, Long et al. (2010b) found an application rate of 1 to 2 ounces per 600 -foot furrow using the patch method reduced sediment loss between 57 and $97 \%$ in numerous trials. Furrow flow rates averaged 17.5 gallons per minute. They found greater than $80 \%$ sediment control in $60 \%$ of the trials. The concentration of a pyrethroid, lambda-cyhalothrin, or zeta-cypermethrin was reduced by the same amount.

\section{Landguard OP-A Degradation Enzyme}

Runoff water containing organophosphate insecticide residues can be treated with Landguard OP-A, a degradation enzyme, to reduce or eliminate residues in runoff water before water exits the farm. This product promotes the breakdown of most organophosphate pesticides into less-toxic metabolites. The powder-like enzyme is mixed with water into a stock solution and applied to runoff water, usually in the tailwater ditch but sometimes in a holding basin. The enzyme treatment rate, residue concentration, and the time available before runoff discharge are all important to for ensuring degradation at a minimum material cost. A longer time between treatment and runoff water discharge allows for a lower enzyme application rate.

The key factor in determining the correct application rate is the maximum expected runoff rate. The runoff rate is typically not constant over time. When using a single application rate based on the maximum estimated flow rate, overapplication is likely at the lower flows that typically occur at the beginning and end of runoff. Additionally, the practice of irrigating more furrows or checks during a nighttime set can lead to different peak flows of different duration.

A comparison was made of the amount of enzyme required for single-maximum-rate application for an entire runoff period and for a variable rate dosed as required by flow rate, essentially keeping the application rate constant (Prichard and Antinetti 2009). A single rate for the maximum runoff rate during the first irrigation resulted in a enzyme application rate of more than double the amount needed. Estimating that the next set would have nearly the same runoff flow rate and using the same application rate, the second set required over 6 times the rate of a correctly managed variable system do to the lower amount of runoff.

\section{Effectiveness in removing pesticide residues}

A field trial in California found chlorpyrifos in runoff at a concentration near 10 parts per billion ( $\mathrm{ppb}$ ) prior to Landguard OP-A treatment; 12 minutes after the enzyme was added at a rate of 4.3 ounces per acre-foot of runoff water, the chlorpyrifos concentration declined to $0.4 \mathrm{ppb}$ (Weston and Jackson 2010). At higher rates, chlorpyrifos became undetectable. The effects of the enzyme on chlorpyrifos-related toxicity are equally dramatic. The enzyme reduces chlorpyrifos toxicity to Hyalella azteca (a test organism) by at least 70 -fold compared with untreated water. Without the enzyme, the concentration of chlorpyrifos required to kill half the test organisms was $141 \mathrm{ppb}$; with enzyme, none of the test organisms were killed.

A team led by Brian Anderson of the UC Davis Marine Pollution Studies Laboratory applied Landguard OP-A at the rate of 4.3 ounces per acre-foot of runoff water directly into a drainage 
ditch containing diazinon residues (Anderson et al. 2008). Samples of runoff water were collected from the ditch before application and 107 feet downstream from the electronic application unit (fig. 16). In multiple trials, Anderson found that samples treated with Landguard OP-A removed all detectable diazinon, and all were nontoxic to Ceriodaphnia dubia, another aquatic arthropod test organism.

\section{Risk Analysis Case Study: Codling Moth}

The management practices presented in this manual have been proven to effectively reduce pesticide-related water quality problems arising from orchard operations. The following case study expands on the walnut orchard example introduced earlier in this publication and illustrates how specific changes can be made in orchard operations to reduce pesticide movement from the orchard.

Orchard/Site: Mature walnuts, 32 acres, not organic

Topography: 0 to $2 \%$ slope.

Soil: Hollenbeck silty clay loam soil that tends to crust, limiting the water infiltration rate and leading to runoff in mid to late season.

Irrigation water: $\mathrm{pH} 7.5, \mathrm{EC} 0.2 \mathrm{dS} / \mathrm{m}$.

Irrigation system: Full-coverage sprinklers, application rate $0.10 \mathrm{in} / \mathrm{hr}$.

Irrigation operation: $50 \mathrm{hr}$ per 14-day period at midseason.

Irrigation runoff: runoff is relatively small in volume -carrying little or no sediment.

Drainage: Mid- to late-summer runoff moves to a drainage ditch at the edge of the field, then on to a larger creek.

Proximity to surface water: During the spring and summer, a drainage ditch along one edge of the orchard often contains irrigation runoff water from adjacent lands.

Pesticide mixing and loading: A pesticide mixing and loading area is located 40 -feet from the drainage ditch.

Pest: codling moth, damage was $4 \%$ last season and first flight trap catches this year average 1.5 moths/trap/night in 1 mg pheromone traps

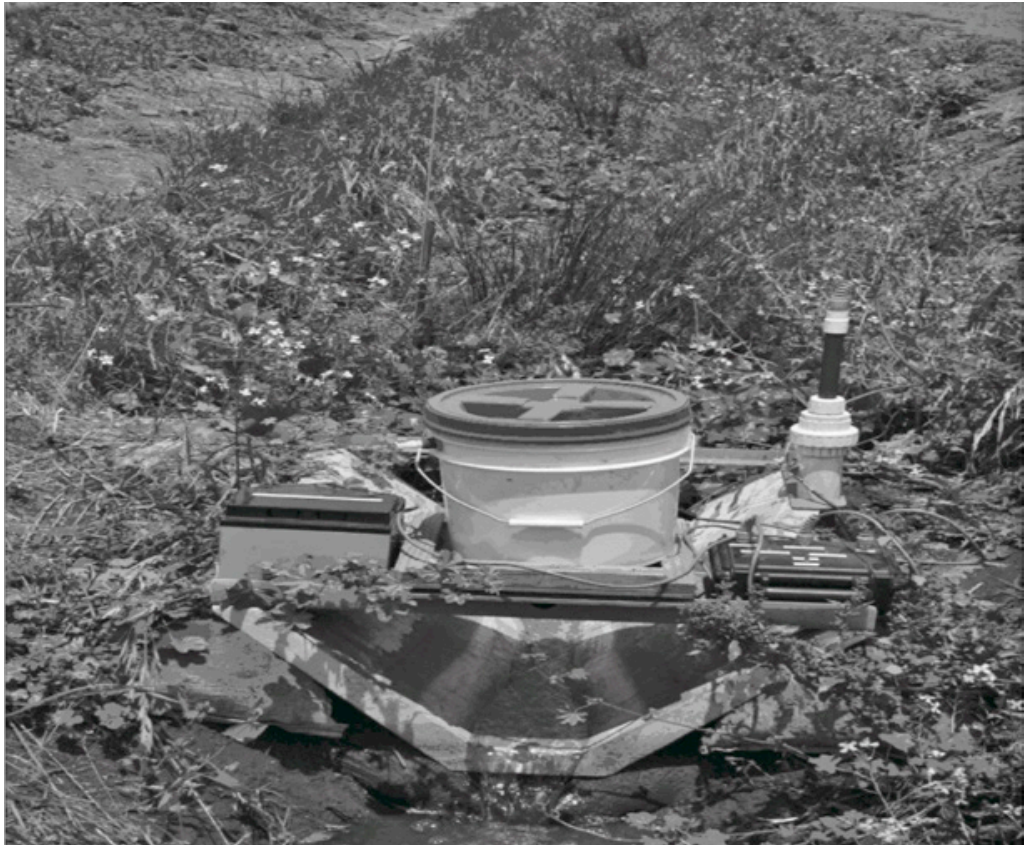

Figure 16. Anderson trial showing vegetated ditch and electronic dosing unit 2008. Photo by B. Anderson

We begin the risk assessment with Flowchart 1 (FC1), considering possible routes by which pesticide could move off the field and the operations or conditions that may contribute or mitigate the risk. We will determine whether a risk exists for irrigation runoff, storm water runoff, and application near surface water: spray Drift, then review management practices to mitigate the risk.

\section{Irrigation Runoff Risk}

We begin with Flowchart 1 (FC1) to evaluate risks associated with irrigation runoff in our orchard using pressurized irrigation. Although runoff from irrigation is unlikely with the use of solidset sprinklers, some runoff does occur in this orchard. Essentially, the poor water infiltration characteristics of this soil, combined with the need to meet the mid-season peak water demand, result on runoff to a surface water ditch and then on to a creek. After 
evaluating the irrigation runoff risks and reviewing management practices, we will revisit FC1 to evaluate the risks of applications near surface water, and finally evaluate the storm water runoff risks.

\section{Integrated Pest Management}

Proceeding to FC2, the next step is to consider walnut orchard IPM practices for codling moth that might help reduce pesticide runoff risks. These are presented in detail in UC IPM Guidelines for Walnuts, ipm.ucdavis.edu/PMG/selectnewpest.walnuts.html.

\section{Codling moth}

Codling moths overwinter as full-grown larvae that pupate and begin emerging as the first flight of adult moths from early March to early April. Depending on the climate, codling moth may have two to three generations per year, with a partial fourth generation in the warmest years and locations. Eggs laid by first-flight moths hatch into larvae that bore into nutlets through the blossom end. Most of these nuts drop to the ground before the nuts mature, reducing yield. Larvae of subsequent generations bore into walnuts anywhere on their surfaces, but they often enter where two nuts touch each other. If the shell has hardened, it may take them up to a week to enter the nut. These nuts usually remain on the tree but are unmarketable because of the damage to the kernel.

\section{CODLING MOTH MONITORING}

Sticky traps baited with pheromone (or pheromone plus DA kairomone) and daily temperature records are used to track the seasonal development of codling moth and time spray applications. Codling moth development in each generation, from egg to larva to adult, depends on temperature: warmer temperatures promote faster development. The need for treatment and the timing of sprays is slightly different for each generation of codling moth and depends on the timing of the population. The development of each generation can be predicted very accurately by determining the start of the flight, called the biofix, measuring daily high and low temperatures, and calculating each day's incremental heat accumulation, expressed in units called degree-days (DD). Pesticides that kill by contact or ingestion are generally applied to kill larvae after they emerge from eggs. Insect growth regulators are generally applied earlier, either before egg laying or egg hatch, depending on the product and its specific mode of action.

\section{MANAGEMENT OPTIONS}

- Biological control. While natural enemies present in walnut orchards may help control codling moth, they generally do not provide enough suppression to eliminate the need for chemical treatments.

- Chemical control. In our example orchard, codling moth pressure would be considered moderate based on last season's damage of $4 \%$. Pheromone mating disruption could be an effective tool for reducing codling moth population and damage in the orchard over time, but, according to our case study conditions, our first flight trap catches of 1.5 per trap per night indicate the need for a late first-generation (1B) treatment at 600 to 700 degree-days. Treatments for subsequent generations depend on the results of monitoring nut drop, trap catches, and canopy damage. In orchards treated with contact or ingested insecticides (e.g., spinosad and oil, organophosphates, pyrethroids, or carbamates), treatments should be timed to kill larvae as they emerge from eggs. If insect growth regulators are used, treatments should be applied before egg laying or egg hatch, depending on the product being used.

\section{Selecting pesticides to reduce water quality risks}

Continuing to work our way through FC2, the next step is to select an effective pesticide that has a minimal risk to water quality.

To illustrate how pesticides might be selected based on water quality considerations, let's assume that a second codling moth treatment is needed later in the season to control the second codling moth generation. Treatment options cane be derived from the UC IPM Pest Management Guidelines for Walnuts. A variety of chemicals of different classes are available for treatment. Consideration should be given to efficacy, costs, and surface water protection when a sensitive area is nearby or if runoff reaches 
water sources. Table 11 lists the chemicals available for use within the different pest pressure population groups. Table 11 also includes the potential for solution and adsorption runoff as well as an overall runoff risk that considers the aquatic toxicity of the pesticide.

Our example orchard has a moderate population, and the table includes ten insecticides considered appropriate for moderate or moderate to high populations: two organophosphates, five pyrethroids, one spinosyn, one carbamate, and one diacylhydrazine.
From the sections of this publication about the water quality risks associated with various classes of chemicals, we know that organophosphates are highly water soluble; pyrethroids are much less soluble, but they adsorb readily to soil sediments. Selection should be made based on pesticide efficacy, costs, and the risk of offsite movement from the orchard. In our example orchard, there is a risk of a small volume of irrigation runoff, which should encourage the use of pesticides with a low solution runoff potential, as indicated in table 11 .

Table 11. Common treatment options for populations of codling moth in walnut production

\begin{tabular}{|c|c|c|c|c|c|}
\hline Chemical name & Trade name & Chemical class & $\begin{array}{l}\text { Solution runoff } \\
\text { potential }^{*}\end{array}$ & $\begin{array}{l}\text { Adsorption } \\
\text { runoff potential }{ }^{+}\end{array}$ & $\begin{array}{l}\text { Overall runoff } \\
\text { risk§ }\end{array}$ \\
\hline \multicolumn{6}{|l|}{ High population } \\
\hline methyl parathion & Penn-Cap & organophosphate & intermediate & intermediate & moderate \\
\hline \multicolumn{6}{|c|}{ Moderate to high population } \\
\hline bifenthrin & Brigade & pyrethroid & low & high & high \\
\hline chlorantraniliprole & Altacor & ryanoid & & & \\
\hline cyfluthrin & Baythroid & pyrethroid & low & intermediate & high \\
\hline lambda-cyhalothrin & Warrior & pyrethroid & low & intermediate & high \\
\hline spinetoram & Delegate & spinosyn & & & \\
\hline \multicolumn{6}{|l|}{ Moderate population } \\
\hline acetamipirid & Assail & neonicotinoid & & & \\
\hline carbaryl & Sevin & carbamate & intermediate & low & moderate \\
\hline chlorpyrifos & Lorsban & organophosphate & high & intermediate & very high \\
\hline emamectin benzoate & Proclaim & macrocyclic lactone & & & \\
\hline esfenvalerate & Asana XL & pyrethroid & low & high & high \\
\hline flubendiamide & Belt & ryanoid & & & \\
\hline methoxyfenozide & Intrepid & diacylhydrazine & & & \\
\hline permethrin & Pounce & pyrethroid & low & high & high \\
\hline phosmet & Imidan & organophosphate & intermediate & low & moderate \\
\hline \multicolumn{6}{|l|}{ Low population } \\
\hline diflubenzuron & Dimilin & benzoylurea & high & intermediate & low \\
\hline spinosad & Entrust & spinosyn & intermediate & intermediate & low \\
\hline
\end{tabular}

Notes:

"Likelihood that the active ingredient will transport from the area of treatment as dissolved chemical in runoff.

tLikelihood that the active ingredient will transport from the area of treatment as attachment to soil or sediment particles in runoff.

${ }^{\S}$ Overall likelihood to cause negative impact on surface water quality as a product of the runoff potential and the aquatic toxicity of the pesticide. 


\section{Mixing and loading pesticides near surface water}

The next consideration in FC2 for managing codling moth is to consider pesticide mixing and loading practices and their impact on surface water quality.

The mixing and loading site in our example orchard is within 50 feet of a surface water ditch. Mixing and loading practices include not over-filling the tank, triple-rinsing containers and adding the rinsate to the tank, and rinsing the tank and applying the rinsate to the orchard. The use of a concrete pad with catchment sump is also a good solution to reduce risks from mixing and loading near surface water sources.

\section{Irrigation System Management}

The next step in our assessment in FC2 is to consider changes in irrigation system management. In our example orchard, runoff to a drainage ditch and nearby creek occurs during mid- and late-summer irrigations.

\section{Change irrigation frequency or application rate}

In addition to making changes that improve water infiltration, it may be possible to modify the example orchard's irrigation schedule to help reduce runoff. With the current schedule, 5 acre-inches of water are applied every 14 days in midsummer. The 14-day midsummer $\mathrm{ET}_{\mathrm{c}}$ for mature walnuts is 4.5 inches. Meeting this demand requires the application of 6 inches of water, because the irrigation efficiency of our sprinkler system is roughly $75 \%$. Thus, the current irrigation of 5 inches every 2 weeks is 1 inch below the requirement. Any new schedule must correct this deficiency and reduce runoff.

One possible solution is to change the irrigation interval to 7 days and the duration to 30 hours. This schedule would meet the orchard's demand while reducing the likelihood of runoff by reducing irrigation duration, avoiding the part of the irrigation with the lowest intake rate. Another possible solution is to reduce the application rate by $20 \%$ in an attempt to not exceed the infiltration capacity. However, a longer irrigation time would be necessary to meet the irrigation requirement.

\section{Improve water infiltration}

The soil is our example orchard prone to crusting. Winter annual cover crops may help protect the soil surface from the dispersive effects of winter and spring rainfall and improve water infiltration during the summer by increasing soil organic matter content. Light tillage in the spring and summer can be used to break up surface crusts. If done after a pesticide application, tillage may also help incorporate pesticide residues into the soil, reducing runoff potential.

The irrigation water in our example orchard has a salinity $\left(\mathrm{EC}_{\mathrm{w}}\right)$ of $0.2 \mathrm{dS} / \mathrm{m}$, indicating a "pure water" infiltration problem. Applying gypsum (with a solutionizer in the irrigation water or broadcast and left on the surface to be dissolved by the sprinkler irrigation water) would help improve water infiltration.

\section{Improve irrigation uniformity}

Uniformity must be designed into pressurized irrigation systems during the orchard planning process. Sprinkler nozzle wear can increase application rates, exceeding the infiltration rate at the end of the irrigation when infiltration rate declines. All nozzles should be the same size to minimize pressure differentials.

\section{Manage irrigation system to avoid runoff}

The simplest way to avoid irrigation runoff is to turn the system off before runoff occurs at the end of each irrigation. The irrigation frequency may need to be to be increased to compensate for shorter irrigation duration.

\section{Irrigation scheduling}

The next step in our assessment in FC2 is to consider changes in irrigation scheduling. Irrigation scheduling entails estimating the amount of crop water use, then applying this amount plus an amount to overcome system efficiencies to ensure that most parts of the orchard receive the minimum water required.

Irrigations should be scheduled before significant water stress is experienced at durations that do not cause runoff. Use soil-based or plant-based monitoring methods used to check the irrigation calculations and applications. 
Runoff Water Capture, Filter, and Recycling

The next step in our assessment in FC2 is to consider runoff water capture, filtering, and recycling.

\section{Sediment basin/recycle runoff}

Sediment basins can capture runoff and reduce sediment load. Recycling runoff water to the delivery system can completely eliminate offsite runoff. Installing a sediment basin upstream of the drainage ditch or creek could prevent runoff, but its capacity would need to be great enough to hold the runoff water long enough for it to infiltrate before the next runoff event. Another option is to install a berm at the lower end of the orchard to trap and hold runoff water long enough for it to infiltrate the soil.

\section{Vegetated strips and drain ditches}

Vegetative strips, if designed and constructed properly, can infiltrate runoff water and filter out sediments. Take care to create a large enough strip or ditch areas to reduce runoff velocities.

\section{Runoff water treatment}

The last step in our assessment in FC2 is to consider runoff water treatment. Runoff water from our example orchard is low in volume and generally does not carry sediments, confining the offsite movement to water-soluble organophosphate pesticides. Runoff water containing organophosphate insecticide residues can be treated with the degradation enzyme Landguard OP-A to reduce or eliminate residues in runoff water before the water exits the farm. This product promotes the breakdown of most organophosphate pesticides into less-toxic metabolites.

\section{Storm Water Runoff Risk}

Now that we have evaluated the risk of chemical applications near surface water, we go back to FC1 to evaluate the storm water runoff risk. In our example orchard, all codling moth applications are in season, allowing for residue degradation prior to the storm water runoff season. Therefore, there is little risk of offsite movement of pesticide residues in our example.

\section{Application Near Surface Water Risk (Drift)}

Now that we have evaluated the storm water runoff risk, we go back to $\mathrm{FC} 1$ to evaluate the application sear surface water risks. Our example orchard is located near a drainage ditch that contains water draining to a surface water source and therefore poses a significant risk. We must consider reducing spray drift that could enter the drainage ditch or creek near the example orchard (see FC5). Options for accomplishing this include the following.

\section{Application Conditions}

- Do not apply pesticides under calm conditions, in which drift can easily migrate, or in windy or gusty conditions. Don't apply at wind speeds greater than $10 \mathrm{mph}$, ideally not over $5 \mathrm{mph}$. Read the pesticide label for specific instructions.

- Apply pesticides early in the morning or late in the evening when the air is usually calmer than during the day.

- Determine wind direction and take it into account when deciding whether and how to make an application.

- Calibrate and adjust sprayers to accurately direct the spray into the crop canopy target.

- Delay treatments near ditches and surface water until wind is blowing away from these and other sensitive areas.

- Don't spray during thermal inversions, when air close to the ground is warmer than the air above it.

\section{Application Equipment}

- Use the coarsest spray possible (250 to 400 microns or larger) while still obtaining good coverage and control. Droplet size is one of the most important factors affecting the potential for drift.

- Use low-drift nozzles that produce large droplet sizes. Fitting a sprayer with air-induction nozzles reduces spray drift up to $50 \%$ compared with standard nozzles.

- Check to verify the spray deposition pattern.

- Service and calibrate spray equipment regularly. 
- Check the system for leaks. Small leaks under pressure can produce very fine droplets. Large leaks contaminate soil that can be moved offsite by water.

- Use low pressure and spray volumes appropriate for canopy size.

\section{Product Choice}

- Choose an application method that is less likely to cause drift. After considering the drift potential of a product, formulation, or application method, it may become necessary to use a different product to reduce the chance of drift.

- Use drift control or drift reduction spray additives. These materials are generally thickeners that minimize the formation of droplets smaller than 150 microns. They also help produce a more consistent spray pattern and deposition.

- Use spray adjuvants, which can greatly reduce application volumes without compromising pesticide efficacy.

- Apply the maximum spray volume per acre under low pressure.

\section{Buffer Zones}

- Follow label requirements on required buffer zones between the orchard and nearby waterways.

- Treat buffer zones separately with insecticides that are permitted and that represent a lower risk to aquatic life.

\section{REFERENCES}

Anderson, B. S., B. M. Phillips, J. W. Hunt, B. Largay, and R. Shihadeh. 2008. Pesticide and toxicity reduction using vegetated treatment systems and Landguard OP-A. Data Summary and Final Report. San Luis Obispo: Central Coast Regional Water Quality Control Board.

Ayers, R. S., and D. W. Westcott. 1985. Water quality for agriculture. United Nations FAO Irrigation and Drainage Paper 29 , rev. 1.

Bondarenko, S. J., and J. Gan. 2004. Degradation and sorption of selected organophosphate and carbamate insecticides in urban stream sediments. Environmental Toxicology and Chemistry 23:1809-1814.

Cole, J. T., J. H. Baird, and B. T. Basta. 1997. Influence of buffers on pesticide and nutrient runoff from bermudagrass turf. Journal of Environmental Quality 26:1589-1598.

de Vlaming, V., L. Deanovic, and S. Fong. 2004. Investigation of water quality in agricultural drains in the California Central Valley. Sacramento: California State Water Resources Control Board.

Fulton, A., R. Buchner, J. Grant, T. Prichard, B. Lampinen, L. Schwankl, and K. Shackel. n.d. Tentative guidelines for interpreting pressure chamber readings (midday stem water potential, SWP) in walnut, almond, and dried plum, 2003 season. UC ANR Drought Management website, ucmanagedrought.ucdavis.edu/PDF/UCCE\%20-\%20Walnut, $\% 20$ Almond\%20and\%20Prune.pdf.

Gill, S., F. C. Spurlock, K. S. Goh, and C. Ganapathy. 2008. Vegetated ditches as a management practice in irrigated alfalfa. Environmental Monitoring and Assessment 144:261-267.

Grant, J., K. Anderson, T. Prichard, J. Hasey, B. Bugg, F. Thomas, and T. Johnson. 2006. Cover crops for walnut orchards. Oakland: University of California Agriculture and Natural Resources Publication 21627. 
Grismer, M. E., T. O’Geen, and D. Lewis. 2006. Vegetative filter strips for nonpoint pollution control in agriculture. Oakland: University of California Agriculture and Natural Resources Publication 8195. UC ANR website, http://anrcatalog.ucanr.edu/pdf/8195.pdf.

Hanson, B., and L. Schwankl. 1995. Surface irrigation. Water Management Series Publication 94-01. UC Irrigation Program, University of California, Davis, Department of Land, Air, and Water Resources. LAWR website, http://lawr.ucdavis.edu/ irrigation/manuals/94-01.html.

Ingels, C. A., R. L. Bugg, G. T. McGourty, and L. P. Christensen. 1998. Cover cropping in vineyards: A grower's handbook. Oakland: University of California Division of Agriculture and Natural Resources Publication 3338.

Karkoski, J. 2008. Management plan. San Joaquin County Delta Water Quality Coalition, Central Valley Regional Water Quality Control Board, September 30, 2008.

Long, R. F., J. Gan, and M. Nett. 2005. Pesticide choice: Best management practices (BMP) for protecting surface water in agriculture. Oakland: University of California Agriculture and Natural Resources Publication 8161. UC ANR website, http://anrcatalog.ucanr.edu/pdf/8161.pdf.

Long, R. F., A. Fulton, and B. Hanson. 2010a. Protecting surface water from sediment-associated pesticides in furrow-irrigated fields. Oakland: University of California Agriculture and Natural Resources Publication 8403. UC ANR website, http://anrcatalog. ucdavis.edu/Items/8403.aspx.

Long, R. F., B. R. Hanson, A. E. Fulton, and D. Weston. 2010b. Mitigating technicques reduce sediment in runoff from furrowirrigated cropland. California Agriculture 64(3): 135-140.

Markle, J .C. 2009. Efficacy of settlement ponds for reducing pyrethroid runoff in almond orchards. Almond Board of California Final Research Report.
Moore, M. T., E. R. Bennet, C. M. Cooper, R. W. Smith, F. D. Shields, C. D. Milam, and J. L. Farris. 2001. Transport and fate of atrazine and lambda-cyhalothrin in a vegetated drainage ditch in the Mississippi Delta. Agriculture Ecosystems and Environment 87:309-314.

Moore, M. T., D. L. Denton, C. M. Cooper, J. Wrysinski, J. L. Miller, K. Reece, D. Crane, and P. Robins. 2008. Mitigation assessment of vegetated drainage ditches for collecting irrigation runoff. Journal of Environmental Quality 37:486-493.

NRCS (USDA Natural Resources Conservation Service). 2006. National conservation practice standard, irrigation system, tailwater recovery. Standard 447-1.

O'Geen, A. T., R. Elkins, and D. Lewis. 2006a. Erodibility of agricultural soils with examples in Lake and Mendocino Counties. Oakland: University of California Agriculture and Natural Resources Publication 8194. UC ANR website, http://anrcatalog. ucdavis.edu/pdf/8194.pdf.

O'Geen, A. T., T. L. Prichard, R. Elkins, and G. S. Pettygrove. 2006b. Orchard floor management practices to reduce erosion and protect water quality. Oakland: University of California Agriculture and Natural Resources Publication 8202. UC ANR website, http://anrcatalog.ucdavis.edu/pdf/8202.pdf.

PAN (Pesticide Action Network). PAN Pesticide Database 2008. PAN website, http://www.pesticideinfo.org.

Prichard, T. L., and R. Antinetti. 2009. Managing organophosphate pesticide residues using degradation enzymes. Proceedings: American Society of Agronomy, California Plant and Soil Conference.

Ramos, D. 1998. Walnut production manual. Oakland: University of California Agriculture and Natural Resources Publication 3373. 
Schulz, R., 2004. Field studies on exposure, effects, and risk mitigation of aquatic nonpoint-source insecticide pollution:

A review. Journal of Environmental Quality 33:419-448.

Schwankl, L. J., and T. L. Prichard. 2009a. Plant-based irrigation scheduling. UC ANR Drought Management website, http://ucmanagedrought.ucdavis.edu/pbis.cfm.

___ 2009b. Soil-based irrigation monitoring. UC ANR Drought Management website, http://ucmanagedrought.ucdavis.edu/smm.cfm.

Schwankl, L. J., and T. L. Prichard, and B. R. Hanson. 2007a. Storing runoff from winter rains. Oakland: University of California Agriculture and Natural Resources Publication 8211, http://anrcatalog.ucdavis.edu/pdf/8211.pdf

Schwankl, L., T. L. Prichard, B. Hanson. 2007b. Reducing runoff from irrigated lands: Tailwater return systems. Oakland: University of California Agriculture and Natural Resources Publication 8225. UC ANR website, http://anrcatalog.ucanr.edu/pdf/8225.pdf.

Singer, M., J. D. Oster, A. Fulton, W. Richardson, and T. Prichard. 1992. Water penetration problems in California soils: Diagnoses and solutions. University of California, Davis, Kearney Foundation of Soil Science.

Sojka, R. E., D. L. Bjorneberg, J. A. Entry, R. D. Lentz, and W. J. Orts. 2007. Polyacrylamide in agriculture and environmental land management. Advances in Agronomy 92:75-162.

Strand, L. 2003. Integrated pest management for walnuts. Oakland: University of California Agriculture and Natural Resources Publication 3270.
Trout, T. J., R. E. Sojka, and R. D. Lentz. 1995. Polyacrylamide effect on furrow erosion and infiltration. Transactions of the ASAE 38:761-765.

UC IPM Pest Management Guidelines for Walnuts. UC IPM website, http://www.ipm.ucdavis.edu/PMG/selectnewpest.walnuts.html.

Watanabe, H., and M. E. Grismer. 2001. Diazinon transport through inter-row vegetative filter strips: Micro-ecosystem modeling. Journal of Hydrology 247:183-199.

Weston, D. P., and C. J. Jackson. 2010. Use of engineered enzymes to identify organophosphate and pyrethroid-related toxicity in toxicity identification evaluations. Environmental Science and Technology 44(5): 1713-1719.

Weston, D. P., and M. J. Lydy. 2010. Urban and agricultural sources of pyrethroid insecticides to the Sacramento-San Joaquin Delta of California. Environmental Science and Technolocy 44(5): 1833-1841.

Weston, D. P., R. D. Lentz, M. D. Cahn, A. K. Rothert, and M. J. Lydy. 2009. Toxicity of various anionic polyacrylamide formulations when used as erosion control agents in agriculture. Journal of Environmental Quality 38:238-247.

Wolf, T. M., A. J. Cessna, B. C. Caldwell, and J. L. Pederson. 2003. Riparian vegetation reduces spray drift deposition into water bodies. In A. G. Thomas, ed., Field boundary habitats: Implications for weed, insect, and disease management. Topics in Canadian Weed Science, vol. 1. Sainte-Anne-de-Bellevue, Québec: Canadian Weed Science Society. 


\section{For FURTHER INFORMATION}

Funding for this publication preparation has been provided in full or part through a grant awarded by the California Department of Pesticide Regulation in Cooperation with the San Joaquin County and Delta Water Quality Coalition, 2010.

To order or obtain ANR publications and other products, visit the ANR Communication Services online catalog at http://anrcatalog.ucanr.edu/ or phone 1-800-994-8849. You can also place orders by mail or FAX, or request a printed catalog of our products from

University of California

Agriculture and Natural Resources

Communication Services

1301 S. 46th Street

Building 478 - MC 3580

Richmond, CA 94804-4600

Telephone 1-800-994-8849

510-665-2195

FAX 510-665-3427

E-mail: anrcatalog@ucanr.edu

()ㅣㄴ The Regents of the University of California

Agriculture and Natural Resources

All rights reserved.

\section{Publication 8460}

ISBN-13: 978-1-60107-851-3

The University of California, Division of Agriculture and Natural Resources (UC ANR) prohibits discrimination against or harassment of any person in any of its programs or activities on the basis of race, color, national origin, religion, sex, gender, gender expression, gender identity, pregnancy (which includes pregnancy, childbirth, and medical conditions related to pregnancy or childbirth), physical or mental disability, medical condition (cancer-related or genetic characteristics), genetic information (including family medical history), ancestry, marital status, age, sexual orientation, citizenship, status as a protected veteran or service in the uniformed services (as defined by the Uniformed Services Employment and Reemployment Rights Act of 1994 [USERRA]), as well as state military and naval service.
UC ANR policy prohibits retaliation against any employee or person in any of its programs or activities for bringing a complaint of discrimination or harassment. UC ANR policy also prohibits retaliation against a person who assists someone with a complaint of discrimination or harassment, or participates in any manner in an investigation or resolution of a complaint of discrimination or harassment. Retaliation includes threats, intimidation, reprisals, and/or adverse actions related to any of its programs or activities.

UC ANR is an Equal Opportunity/Affirmative Action Employer. All qualified applicants will receive consideration for employment and/or participation in any of its programs or activities without regard to race, color, religion, sex, national origin, disability, age or protected veteran status.

University policy is intended to be consistent with the provisions of applicable State and Federal laws.

Inquiries regarding the University's equal employment opportunity policies may be directed to: Linda Marie Manton, Affirmative Action Contact and Title IX Officer, University of California, Agriculture and Natural Resources, 2801 Second Street, Davis, CA 95618, (530) 750-1318. Email: Immanton@ucanr.edu. Website: http://ucanr.edu/sites/anrstaff/Diversity/Affirmative_Action/.

To simplify information, trade names of products have been used. No endorsement of named or illustrated products is intended, nor is criticism implied of similar products that are not mentioned or illustrated.

An electronic copy of this publication can be found at the ANR Communication Services catalog website, http://anrcatalog.ucanr.edu/.

UC This publication has been anonymously peer reviewed for technical accuracy

PEER by University of California scientists and other qualified professionals. This review process was managed by ANR Associate Editor for Land, Air, and Water Sciences, Anthony O'Geen.

web-2/16-SB/CR 


\section{Assessing the Risk of Offsite Movement of Ag Chemicals to Surface Waters}

Follow the decision tree from each shaded box below to assess risk, based on your conditions. If the risk is significant, continue on to view management practices that may reduce the risk of offsite movement
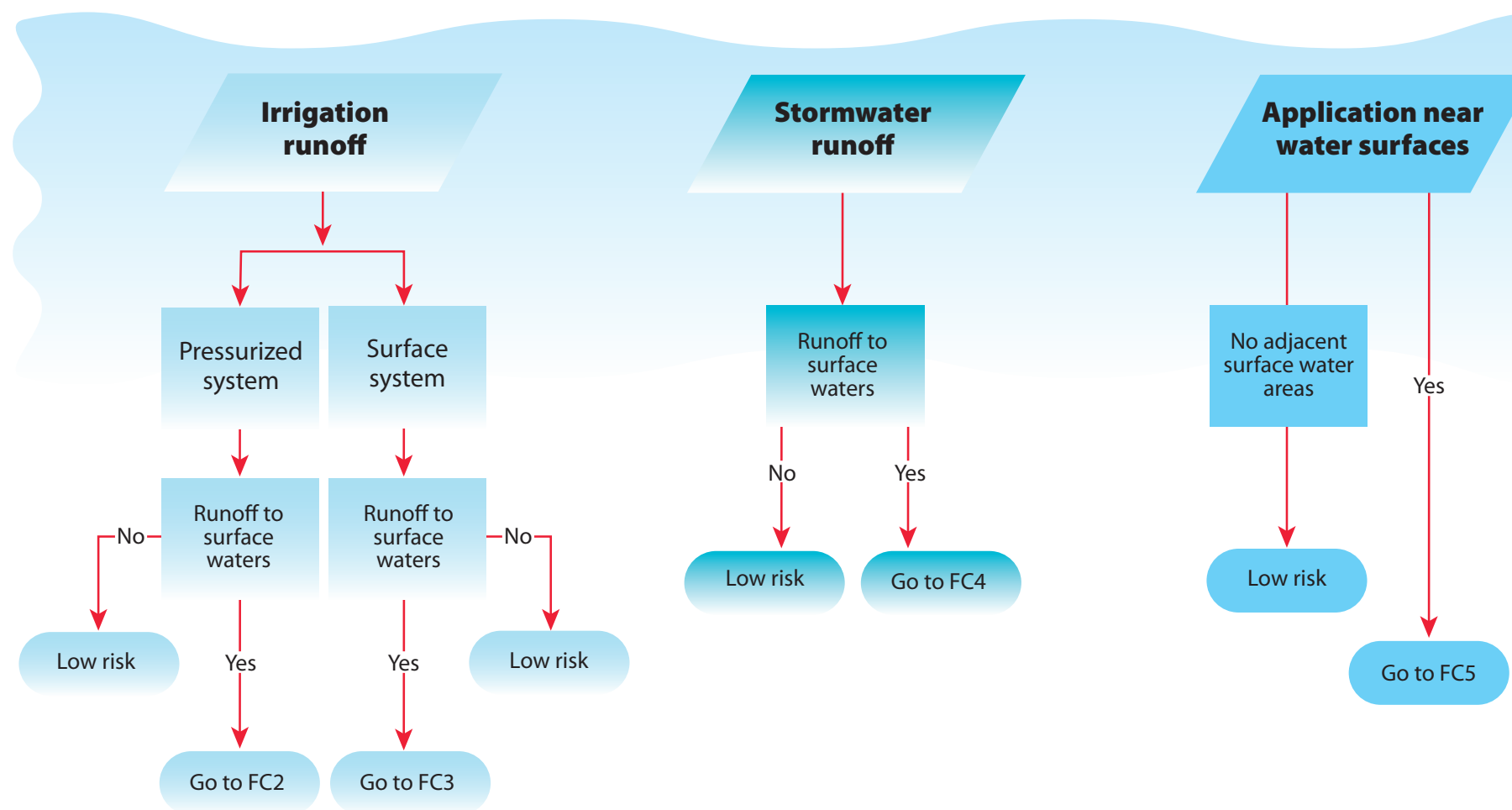


\section{FC2}

\section{Reducing the Risk of Offsite Movement of Ag Chemicals in Runoff}

\section{Pressurized Irrigation Systems}

Runoff to surface waters occurs

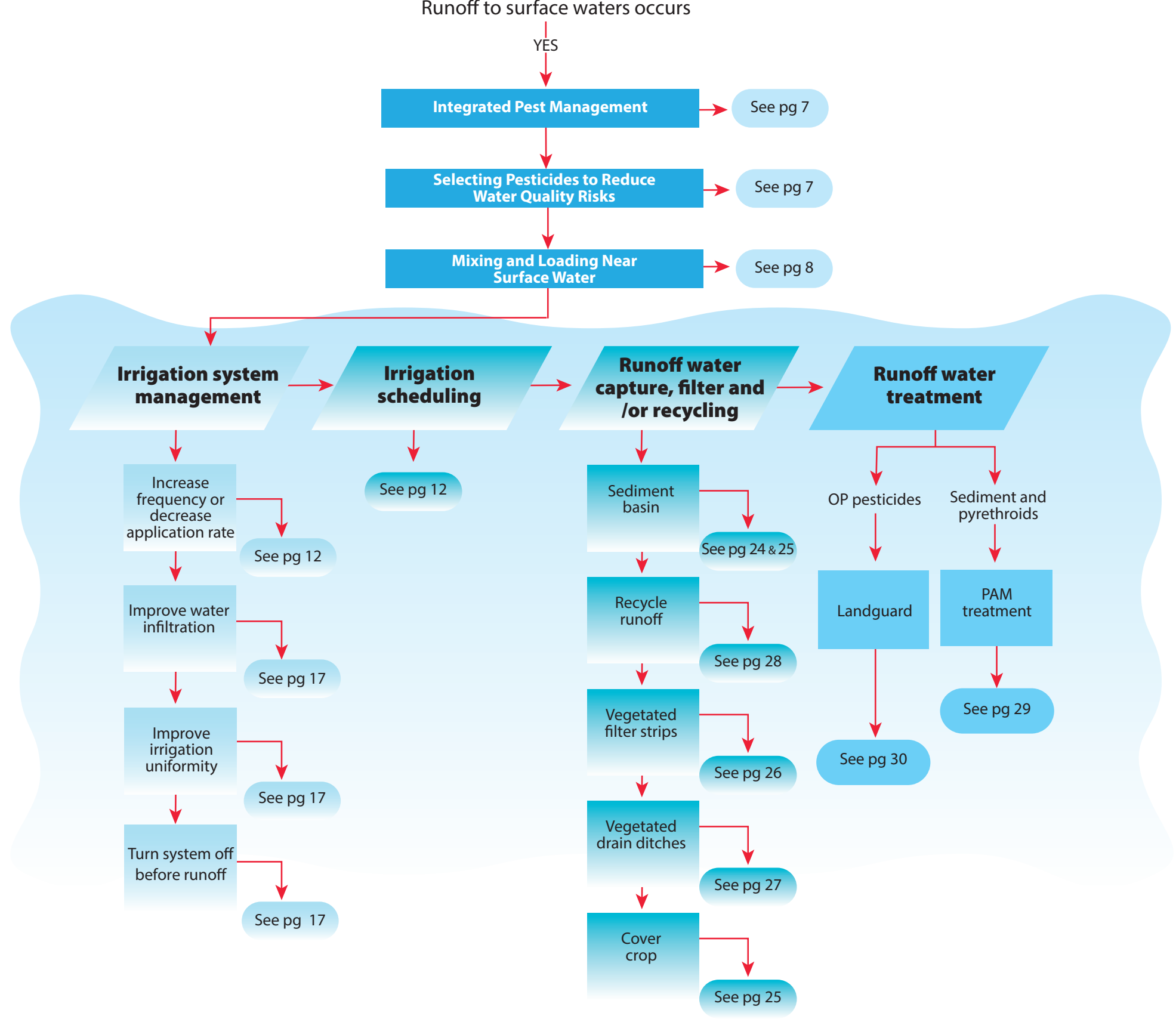




\section{FC3}

Reducing the Risk of Offsite Movement of Ag Chemicals in Runoff Surface Irrigation Systems

Runoff to surface waters occurs
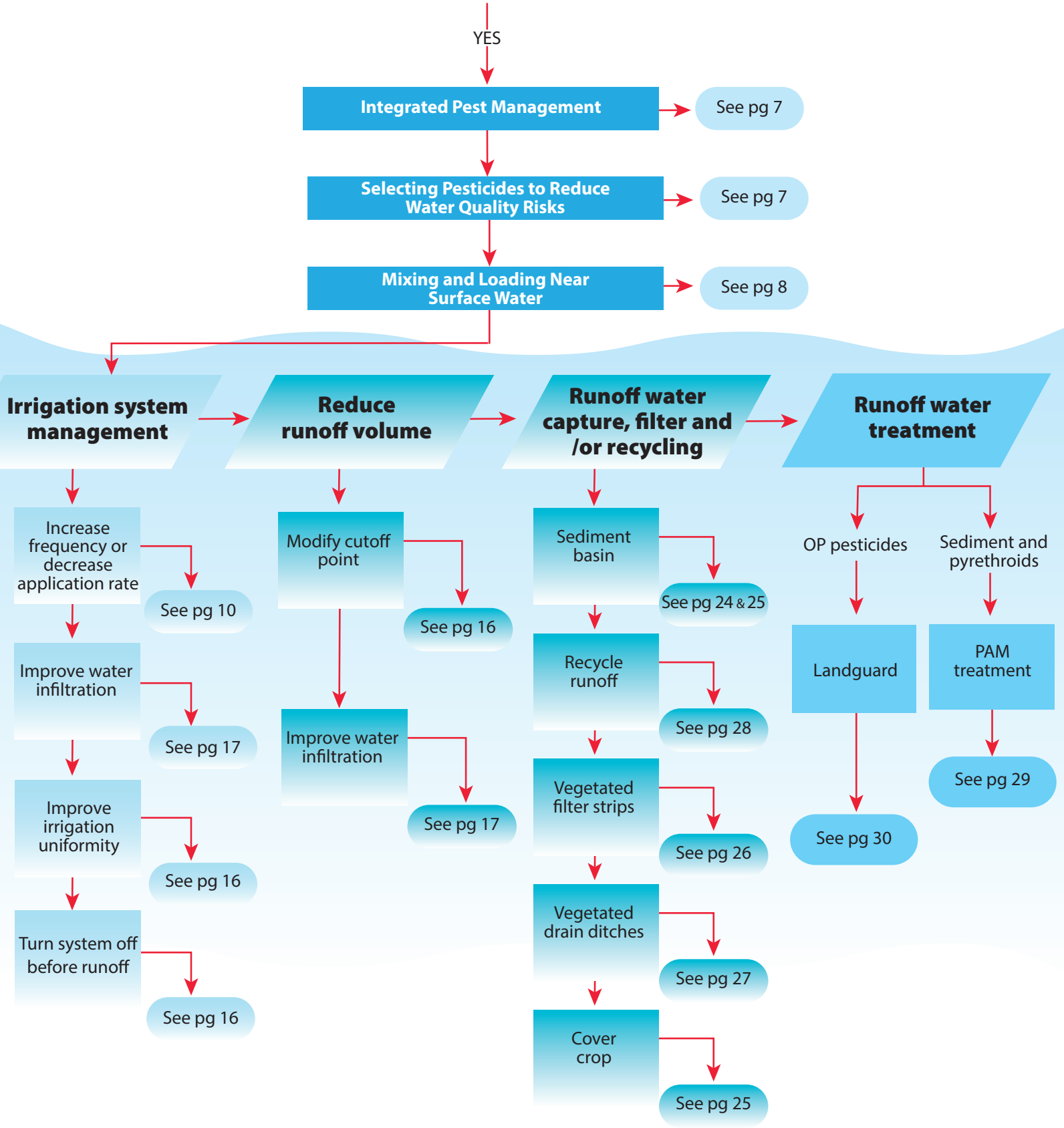


\section{FC4}

Reducing the Risk of Offsite Movement of Ag Chemicals

Stormwater Runoff

Runoff to surface waters occurs

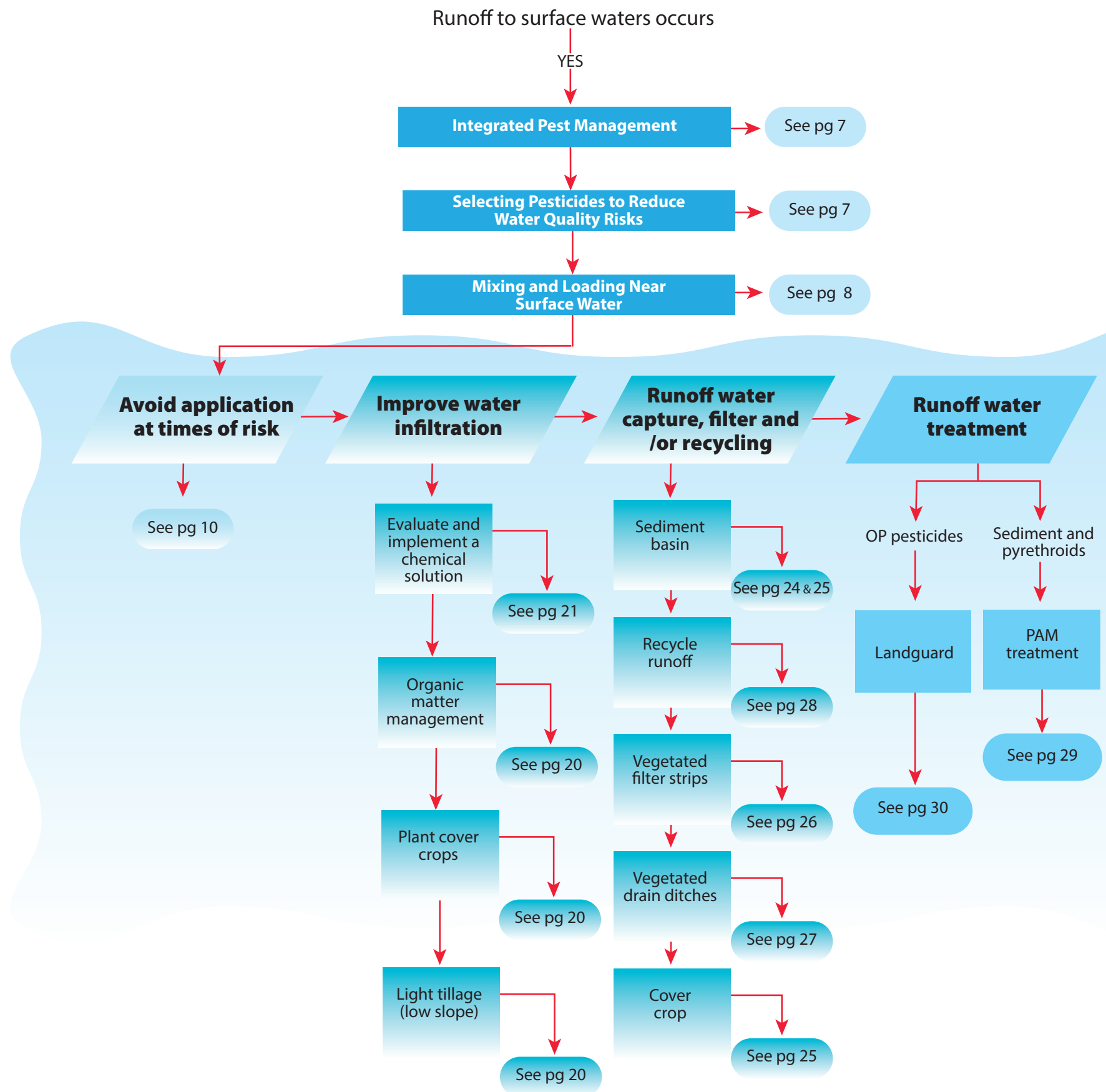


FC5

Reducing the Risk of Offsite Movement of Ag Chemicals Near Water Surfaces in Drift Situations

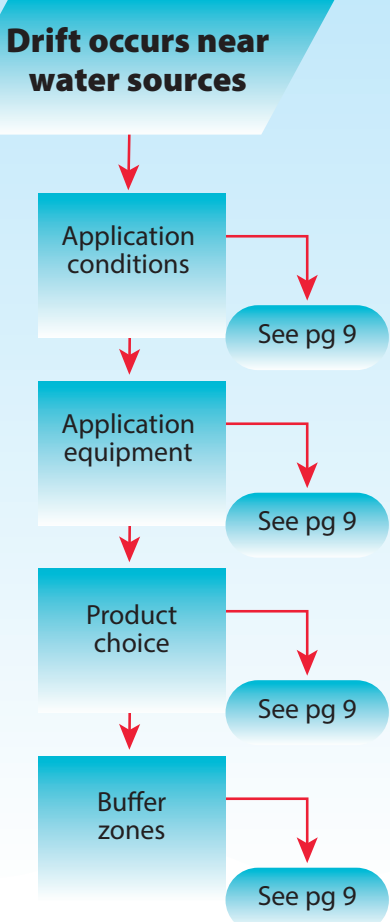

